\title{
Declaring the Death Penalty Unconstitutional
}

\section{Citation}

Arthur J. Goldberg \& Alan M. Dershowitz, Declaring the Death Penalty Unconstitutional, 83 Harv. L. Rev. 1773 (1970).

\section{Published Version}

doi: $10.2307 / 1339687$

\section{Permanent link}

http://nrs.harvard.edu/urn-3:HUL.InstRepos:17209688

\section{Terms of Use}

This article was downloaded from Harvard University's DASH repository, and is made available under the terms and conditions applicable to Other Posted Material, as set forth at http:// nrs.harvard.edu/urn-3:HUL.InstRepos:dash.current.terms-of-use\#LAA

\section{Share Your Story}

The Harvard community has made this article openly available.

Please share how this access benefits you. Submit a story.

Accessibility 


\title{
DECLARING THE DEATH PENALTY UNCONSTITUTIONAL
}

\author{
Arthur J. Goldberg \& Alan M. Dershowitz*
}

In the following article the authors examine the eighth amendment cases that have been heard by the Supreme Court and extract a set of principles by which the Court has tested those punishments challenged as cruel and unusual. They apply these principles to the death penalty and argue that the Court should hold it unconstitutional. The authors then argue that should the Court, for institutional reasons, decline to decide the issue, legislators and executives share the responsibility to make the constitutional determination that capital punishment violates the eighth amendment.

$\mathrm{W}$ $\mathrm{E}$ are in the midst of a great national debate over capital punishment. The debate is being carried on in the legislative, executive and judicial chambers of our state and national governments. For three years official executions have been halted pending the outcome. However, the decision finally to abolish capital punishment has yet to be made in most jurisdictions, and death sentences continue to be imposed. The lives of over five hundred prisoners waiting on death row are immediately at stake. ${ }^{1}$ But also at stake is our faith in and commitment to national selfimprovement, as we decide whether to take what Camus called the "great civilizing step" 2 of abolishing the death penalty. The issue is a highly emotional one. Despite the familiar demonstrations that we have no convincing proof of the death penalty's deterrent effect, ${ }^{3}$ proposals to make the penalty mandatory and expand its applications still proliferate. ${ }^{4}$ Official execution seems

* Arthur Goldberg, B.S.L., I929; J.D., I930, Northwestern, is a member of the New York Bar who served as Secretary of Labor, Associate Justice of the Supreme Court, and U.S. Ambassador to the United Nations. Alan Dershowitz, B.A., Brooklyn College, I959; LL.B., Yale, I962, is Professor of Law at Harvard Law School and was law clerk to Mr. Justice Goldberg during the October, I963 Term of the Supreme Court. The authors express their gratitude to Richard D. Parker, a thirdyear student at Harvard Law School, for his invaluable assistance in the preparation of this article.

${ }^{1}$ Boston Globe, Apr. 20, I97o, at I, col. 3. The last execution in the United States took place on June 2, Ig67 in Colorado.

${ }^{2}$ A. Cauros, Reflections on the Guillotine, in Resistance, Rebertion, aNd DEATH 232 (Ig6I).

${ }^{3}$ See The Death Penalty in Amertca 258-332 (H. Bedau ed. I964); p. I796 infra.

${ }^{4}$ Most of the recent proposals to extend application of the death penalty have focused on the punishment of particular crimes - usually the killing of particular sorts of victims. See N.Y. Times, Mar. I, I970, \& 4, at 8, col. 3 (New York state 
to be a kind of tribal rite, a symbolic palliative for the fear of crime.

Debate over capital punishment has focused primarily on its moral and practical attributes as a government policy. A more basic question is whether capital punishment is constitutionally permissible in this country. The cruel and unusual punishment clause of the eighth amendment is directly in point. Yet the argument that the death penalty is unconstitutional under that clause has been generally avoided or briefly dismissed even in academic journals until recently. ${ }^{5}$ Legislative and executive policy makers seem to feel that their role is not to make their own constitutional interpretations, but to look to the courts. Many state ${ }^{6}$ and lower

senator supports death penalty for narcotics peddlers); N.Y. Times, June r2, I969, at 63 , col. 5 (California Senate approves death penalty for anyone who knowingly kills a police officer); N.Y. Times, Feb. 28, 1968, at 44, col. I (New York Senate votes to reinstate death penalty when murder victim killed while aiding police officer); N.Y. Times, Mar. 28, I968, at 95, col. I (New York Assembly votes to restore death penalty for murder of firemen).

Nonetheless, a review of the New York Times Index for the last three years indicates that proposals to abolish the death penalty or limit its application have substantially outnumbered proposals to make it mandatory or extend its application.

${ }^{5}$ See, e.g., Packer, Making the Punishment Fit the Crime, 77 Harv. L. Rev. I07x, 108I (I964) [hereinafter cited as Packer] ("The Supreme Court is obviously not about to declare that the death penalty simpliciler is so cruel and unusual as to be constitutionally intolerable."); Note, The Cruel and Unusual Punishment Clause and the Substantive Criminal Law, 79 HARv. L. REv. 635, 638-39 (I966) [hereinafter cited as HARVARD Note] ("to hold that [capital punishment] is a method of punishment wholly prohibited by the eighth amendment would be to confuse possible legislative desirability with constitutional requirements"). See also Note, The Effectiveness of the Eighth Amendment: An Appraisal of Cruel and Unusual Punishment, 36 N.Y.U.L. REv. 846 ( $\mathrm{x} 96 \mathrm{I}$ ) [hereinafter cited as N.Y.U. Note]; Note, Revival of the Eighth Amendment: Development of Cruel-Punishment Doctrine by the Supreme Court, I6 STaN. I. REv. 996 (I964) [hereinafter cited as STANFord Note].

Four commenators have argued that capital punishment is unconstitutional. The best of these is Comment, The Death Penalty Cases, 56 CALIF. L. REv. I268 (1968) [hereinafter cited as CaLIFORNIA Note]. See also Bedau, The Courts, the Constitution, and Capital Punishment, I969 UtAH L. Rev. 201; Gottlieb, Testing the Death Penalty, 34 S. Car. L. Rev. 268 (I96r); S. Rubin, The Supreme Court, Cruel and Unusual Punishment, and the Death Penalty (unpublished paper submitted for Congress of Correction, Miami, Fla., Aug. 22, 1967).

${ }^{6}$ For example, in 1969 alone, courts in at least eight states upheld the constitutionality of capital punishment. Rivers v. State, 226 So. 2d 337 (Fla. 1969); Wilson v. State, 225 So. 2d 321 (Fla. I969); Furman v. State, 225 Ga. 253, 167 S.E.2d 628 (I969); People v. Walcher, 42 Ill. 2d I59, 246 N.E.2d 256 (I969); State v. Crook, 253 La. 96I, 22I So. 2d 473 (I969); Duisen v. State, 44I S.W.2d 688 (Mo. I969) ; State v. Pace, 80 N.M. 364,456 P.2d I97 (Ig69); State v. Rogers, 275 N.C. 4II, I68 S.E.2d 345 (I969); State v. Kelbach, 23 Utah 2d 23I, 46I P.2d 297 (I969). 
federal ${ }^{7}$ courts have upheld capital punishment against constitutional attack. But their treatment of the issue has been unusually shallow, generally resolving the question in two or three sentences. Such brief treatment of a properly raised claim is usually explained as strict adherence to Supreme Court precedent.

The Court, however, has never held directly that the death penalty is or is not cruel and unusual punishment. It has heard argument on the issue only once, and then decided the case on other grounds. ${ }^{8}$ Three opinions contain short statements, made in the course of decision on related issues, which suggest that capital punishment is constitutionally permissible. ${ }^{9}$ Yet more recent doctrinal developments have not only undermined these statements, ${ }^{10}$ but also indicated growing concern among the Justices with the operation of the death penalty. ${ }^{11}$ The basic eighth amendment question now hangs in an uncomfortable limbo.

This article will not simply argue that the death penalty is unconstitutional under the eighth amendment. It will also consider the appropriate forums in which the cruel and unusual punishment issue might be decided and the ways in which the issue might be approached and resolved in each forum.

The most obvious and authoritative forum for constitutional interpretation is the Supreme Court. The first part of this article

${ }^{7}$ Sims v. Eyman, 405 F.2d 439, 447-48 (9th Cir. I969); Segura v. Patterson, 402 F.2d 249, 254-55 (Ioth Cir. I968); Powers v. Hauck, 399 F.2d 322, 325 (5th Cir. I968); Harris v. Stephens, 36I F.2d 888, 894-95 (8th Cir. I966); cert. denied, 386 U.S. 964 (1967); Mitchell v. Stephens, 353 F.2d 129, I35 (8th Cir. 1965) (Blackmun, J.), cert. denied, 384 U.S. rorg (Ig66); Maxwell v. Stephens, 348 F.2d 325, 332 (8th Cir.) (Blackmun, J.), cert. denied, 382 U.S. 944 (rg65) ; Ralph v. Pepersack, 335 F.2d I28, I4I (4th Cir. I964), cert. denied, 380 U.S. 925 (I965); Jackson v. Dickson, 325 F.2d 573, 575 (9th Cir. I963), cert. denied, 377 U.S. 957 (I964); United States v. Rosenberg, r95 F.2d 583, 607-08 (2d Cir.), cert. denied, 344 U.S. 838 (I952); Marion v. Beto, 302 F. Supp. 913, 921 (N.D. Tex. I969); Bell v. Patterson, 279 F. Supp. 760, 764-65 (D. Colo.), aff'd, 402 F.2d 394 (Ioth Cir. Ig68); Janovic v. Eyman, 276 F. Supp. 862, 868 (D. Ariz. I967), aff'd, 406 F.2d 3I4, 3 I8 (9th Cir. I969); United States ex rel. Smith v. Nelson, 275 F. Supp. 26I, 266-67 (N.D. Cal. I967), vacated, 390 F.2d 643 (9th Cir. I968); United States v. Coon, 242 F. Supp. 483,485 (N.D. Iowa I965), aff'd, 360 F.2d 550 (8th Cir.), cert. denied, 385 U.S. 873 (I966); United States ex rel. Melton v. Hendrick, 2 r8 F. Supp. 293, 296 (E.D. Pa.), af'd, 330 F.2d 263 (3d Cir. Ig63).

${ }^{8}$ Boykin v. Alabama, 395 U.S. 238 (I969); see p. I798 infra.

${ }^{9}$ Trop v. Dulles, 356 U.S. 86, 99 (I958); Louisiana ex rel. Francis v. Resweber, 329 U.S. $459,463-64$ \& n.4 (I947); In re Kemmler, r36 U.S. 436,447 (189o); see pp. I78r \& 1786 infra.

${ }^{10}$ See pp. $178 \mathrm{r}-88$ infra.

11 See p. 1799 infra. In addition to statements included in recent opinions suggesting opposition to capital punishment, at least two former Justices have fairly recently stated that they are against the death penalty though they would prefer the legislative and executive branches rather than the judiciary to act. See Frankfurter, The Problem of Capital Punishment, in OF LAW AND MEN 77-IO2 (I956); N.Y. Times, July 6, I968, at 42 , col. I (Chief Justice Warren). 
will analyze the Court's past treatment of cruel and unusual punishment cases. It will demonstrate that there now exists a body of coherent, principled doctrine under the clause, and that on the basis of that doctrine the death penalty should be found unconstitutional. But many "unconstitutional" laws remain on the statute books for years without being declared unconstitutional. There are thus two senses in which the term "unconstitutional" may be used: ( $I$ ) as an implication of established doctrine, and (2) as an authoritative judicial declaration. The first part of the article argues that the death penalty is unconstitutional in the initial sense. It concludes that the Court could, consistently with the institutional demands of stare decisis and principled decision, abolish capital punishment. Instead of facing the issue squarely, however, the Court has thus far chosen to avoid a decision on the constitutional merits.

The second part will evaluate that course, considering the various institutional constraints on judicial determination of the constitutionality of capital punishment. Readers familiar with the senior author's dissent in Rudolph v. Alabama ${ }^{12}$ know that he felt, while serving as an Associate Justice, that the Court should decide whether the cruel and unusual punishment clause renders the death penalty unconstitutional, at least in certain cases. It is important, however, to understand the institutional considerations which may be thought to counsel avoidance of decision. They relate exclusively to the peculiar position of the Court, and even if they continue to prevail, they should not affect the willingness of the other branches of government to decide the issue.

The third part will argue that, if the court remains silent, legislatures and executives should nonetheless confront and decide the cruel and unusual punishment issue. There is a tendency to assume that the only proper forum of constitutional interpretation is the judiciary. Since its methods do not appear suited to the institutional purposes and processes of legislatures and executives, and since we have become accustomed in recent years to depending on the Court for constitutional protection, it is thought that the judiciary must have a monopoly on constitutional decisionmaking. In the words of a familiar constitutional law text, "the Court is the Constitution." 13 That view is correct if it means that the Court is the final and authoritative arbiter of the Constitution. It should not mean, however, that the so-called "political branches" must not interpret the Constitution when the

${ }^{12} 375$ U.S. 889 (I963) (dissenting from denial of certiorari) (joined by Douglas and Brennan, JJ.).

${ }^{13}$ A. Mason \& W. Beaney, The Supreme Court in a Free Society i (ig68). 
Court remains silent. Nor should it mean that the other departments may not extend constitutional protections farther than has the Court.

\section{Cruel and Unusual Punishment Doctrine: Precedent and Principled Decision}

Two familiar constraints which apply to judicial interpretation of the Constitution are those imposed by respect for precedent and the requirement of principled decisionmaking. The two are, of course, related. Both derive in part from appreciation of the Court's counter-majoritarian character. They function to insure that the Court does not act as if it had a "roving commission to check other branches of government," 14 and to hold the Court to a mode of constitutional decisionmaking which tends to enhance public respect for the institution, and which insures that novel constitutional interpretations are adaptations of fundamental values deeply rooted in the past. ${ }^{15}$

Both precedent and established principle are somewhat meager under the cruel and unusual punishment clause. Commentary has focused on the "relative desuetude of the eighth amendment . . . largely attributable to the failure of courts and commentators to develop constitutional standards" by which to interpret it and to justify those interpretations. ${ }^{16}$ To be sure, cruel and unusual punishment doctrine is not well developed. The Court has not consistently and explicitly applied any one test under the clause. Indeed, the clause has been substantially discussed - either by members of the majority or the dissent on the Court - on only ten occasions. ${ }^{17}$ Only three decisions since the

${ }^{14}$ A. Cox, The WARRen Court i8 (Ig68).

${ }^{15}$ See A. Bickes, The Least Dangerous Branch 23-26 (I962). Professor Cox has combined the requirements of precedent and principle in a concise formula: "Ability to rationalize a constitutional judgment in terms of principles referable to accepted sources of law is an essential, major element of constitutional adjudication." A. Cox, supra note 14 , at $2 \mathrm{I}$.

${ }^{16}$ Stanford Note at 996 . The Court, too, has been troubled by the imprecision of eighth amendment doctrine. In its first decision dealing with the cruel and unusual punishment clause, it commented that "[d]ifficulty would attend the effort to define with exactness the extent of the constitutional provision ...." Wilkerson v. Utah, 99 U.S. 130, 135-36 (I878). Eighty years later, Chief Justice Warren wrote that "[t]he exact scope of the constitutional phrase 'cruel and unusual" has not been detailed by this Court." Trop v. Dulles, 356 U.S. 86,99 (r958).

${ }^{17}$ Powell v. Texas, 392 U.S. 514 (I968) ; Robinson v. California, 370 U.S. 660 (I962); Trop v. Dulles, 356 U.S. 86 (I958); Louisiana ex rel. Francis v. Resweber, 329 U.S. 459 (I947); Badders v. United States, 240 U.S. $39 \mathrm{r}$ (Igr6); Weems v. United States, 2I7 U.S. 349 (I910); Howard v. Fleming, IgI U.S. I26 (Ig03); O'Neil v. Vermont, I44 U.S. 323 (1892) (dissenting opinions); In re Kemmler, I36 U.S. 436 (r89o); Wilkerson v. Utah, 99 U.S. I30 (1878). 
adoption of the Bill of Rights have interfered with a government's choice of punishments, ${ }^{18}$ and in only one of those were five Justices willing to invoke the clause. ${ }^{19}$ Yet it would be erroneous to conclude, as have several commentators and lower courts, either that Supreme Court precedent has clearly established the constitutionality of the death penalty, or that the Court has failed to generate judicial principles capable of supporting a holding of unconstitutionality.

\section{A. The Evolving Standards of Decency}

Recognizing that "the words of the Amendment are not precise" the Court has concluded that the cruel and unusual punishment clause must be highly elastic in meaning. ${ }^{20}$ But the principle of growth underlying the clause has remained somewhat uncertain. "The Amendment," the Court most recently stated in Trop v. Dulles, "must draw its meaning from the evolving standards of decency that mark the progress of a maturing society." 21 Although this formula has not been used explicitly in other opinions, most of them can be read to fit within its rubric.

The "evolving standards of decency" formula is reminiscent of a similar formula employed earlier in this century under the fourteenth amendment due process clause. Procedural due process doctrine at that time was little more precise than is cruel and unusual punishment doctrine now. Its central theme was protection of "principle[s] of justice so rooted in the traditions and conscience of our people as to be ranked as fundamental." 22 Sometimes applied to forbid governmental actions which offend the "decencies of civilized conduct," ${ }^{23}$ the formula was said by

\footnotetext{
${ }^{18}$ Robinson v. California, 370 U.S. 660 (I962) (criminal punishment for mere status of narcotics addiction unconstitutional); Trop v. Dulles, 356 U.S. 86 (I958) (criminal penalty of expatriation per se unconstitutional); Weems v. United States, 2Iy U.S. 349 (I9IO) (fifteen years at hard labor in ankle chains and additional civil disabilities unconstitutional when imposed for falsification of a public record).

${ }^{19}$ Robinson v. California, 370 U.S. 660 (Ig62). Robinson was also the first decision to hold that the cruel and unusual punishment clause is applicable to the states through the fourteenth amendment due process clause.

${ }^{20}$ Trop v. Dulles, 356 U.S. 86, I00-OI (I958); Weems v. United States, 217 U.S. 349, 373 (I9I0) ("Time works changes, brings into existence new conditions and purposes. Therefore a principle to be vital must be capable of wider application than the mischief which gave it birth.").

${ }^{21} 356$ U.S. at Ior. See also Weems v. United States, 2I7 U.S. 349, 378 (1910) (constitutional protection expands as "public opinion becomes enlightened by a humane justice").

${ }^{22}$ Palko v. Connecticut, 302 U.S. 3I9, 325 (I937) (Cardozo, J.), quoting Snyder v. Massachusetts, 29r U.S. 97, I05 (I934) (Cardozo, J.); see Kadish, Methodology and Criteria in Due Process Adjudication - A Survey and Criticism, 66 YALE L.J. 3I9 (I957).

${ }^{23}$ Rochin v. California, 342 U.S. 165 , I72-73 (I952).
} 
critics to allow the Justices to "roam at will in the limitless area of their own beliefs." 24 In recent years it has been criticized by many members of the Court and dismissed as essentially "subjective." 25

In practice, however, the old due process formula often tended toward another extreme. Justices Cardozo and Frankfurter, its chief champions, disapproved "subjective" tests. They denied looking to their own consciences or personal views for due process values. Rather, they interpreted the clause to protect only those values which were in fact generally accepted and adhered to. As an index of constitutional protection, the Court tended to rely upon objective indicia of attitudes actually prevailing in society. Those objective factors were usually findings of historic and contemporary practice in American, and sometimes Anglo-American, jurisdictions. ${ }^{26}$ The result of this approach, however, was that the due process guaranty was, in the words of one commentator, "drained of any independent integrity as a governing normative principle. It becomes merely a vehicle for delaying the implementation of a change in procedural law until it is accepted by the conscience of a sufficient number of the relevant segments of the community." 27

Like procedural due process, the eighth amendment "evolving standards of decency" formula has been thought to force a choice between essentially subjective standards and interpretation of prevailing public attitudes. ${ }^{28}$ In an effort to avoid the subjective

${ }^{24}$ Rochin v. California, 342 U.S. I65, I74-77 (I952) (Black, J., concurring). See also Adamson v. California, 332 U.S. 46, 68-92 (I947) (Black, J., dissenting); Federal Power Comm'n v. Natural Gas Pipeline Co., 3I5 U.S. 575, 600-oI n.4 (I942) (Black, J., concurring).

${ }^{25}$ E.g., Benton v. Maryland, 395 U.S. 784, 794 (I969) ; Malloy v. Hogan, 378 U.S. I, IO-II (Ig64), quoting Ohio ex rel. Eaton v. Price, 364 U.S. 263, 275 (Ig60) (Brennan, J., dissenting). The senior author of this article set forth the criticism of "extremely subjective and excessively discretionary determination" of procedural due process rights in Pointer v. Texas, 380 U.S. 400, 4I3 (I965) (concurring opinion). Cf. Griswold v. Connecticut, 38I U.S. 479, 496-99 (I965) (concurring opinion) (substantive due process).

${ }^{26}$ See Kadish, supra note 22 , at 327-34.

${ }^{27} I d$. at 345 .

${ }^{28}$ Many lower courts have spoken generally about "contemporary concepts of decency" without referring to specific indicia of those standards. E.g., Jackson v. Bishop, 404 F.2d 57I (8th Cir. I968) (Blackmun, J.). The courts have been careful to recognize in some way limitations on their personal views. One district judge, for example, stated that he would apply the "conscience of a reasonable man." Willoughby v. Phend, 401 F. Supp. 644,646 (N.D. Ind. I969). The conflict between personal reactions and interpretation of prevailing public attitudes was most explicitly articulated by Justice Frankfurter, deploring the state's "insistence on its pound of flesh" but recognizing that public opinion was fairly divided on the death penalty. Justice Frankfurter, however, was applying not the eighth amendment, but the due process clause. Louisiana $e x$ rel. Francis v. Resweber, 329 U.S. 459, 
approach, the Court has generally made reference to external standards. On occasion, some Justices have spoken simply of what "shocks the most fundamental instincts of civilized man" 20 or of what "it is hard to believe that any man of right feeling and heart can refrain from shuddering" at. ${ }^{30}$ Most Supreme Court opinions have emphasized at least one of three objective indicia of sentiment actually prevailing among civilized people: historic usage of particular punishments, ${ }^{31}$ statutory authorization in other jurisdictions, ${ }^{32}$ and general public opinion. ${ }^{33}$

Virtually unanimous opposition to a type of punishment in other jurisdictions or in public opinion has been cited to show that the evolving standards of decency have in fact condemned it as cruel and unusual. Two of the three penalties struck down under the eighth amendment have been said by the Court to be authorized in almost no other civilized jurisdiction; ${ }^{34}$ the third

47 (I947) (concurring opinion). See also United States v. Rosenberg, I95 F.2d 583, 608-o9 (2d Cir. I952) (Frank, J.); Harvard Note at 638.

${ }^{29}$ Louisiana ex rel. Francis v. Resweber, 329 U.S. 459, 473 (I947) (Burton, J., dissenting).

${ }^{30}$ O'Neil v. Vermont, I44 U.S. 333,340 (I892) (Field, J., dissenting).

31 In Wilkerson v. Utah, 99 U.S. I30 (I878), the first cruel and unusual punishment decision, the Court approved execution by shooting, observing that the firing squad had been used in Utah Territory for at least a quarter of a century "and the usages of the army to the present day are that sentences of [this] kind may in certain cases be executed by shooting." Id. at I33.

32 In Weems v. United States, 217 U.S. 349 (I910), the court held unconstitutional a sentence of fifteen years at hard and painful labor in ankle chains (with additional civil disabilities) imposed for the falsification of a public record in the Philippines Territory. Id. at 363-64. This penalty - known as cadena temporal - was of ancient Spanish origin and had been long used in the Philippines but had no equivalent in the United States. The Court ignored historic usage and observed that " $[t]$ here are degrees of homicide that are not punished so severely" in America, and that the federal penalty for a crime like Weems' was nothing more than a large fine. $I d$. at 380 . It concluded that "this contrast shows more than different exercises of legislative judgment. It is greater than that. It condemns the sentence in this case as cruel and unusual." Id. at $38 \mathrm{r}$.

Almost fifty years later, in Trop v. Dulles, 356 U.S. 86 (1958), the Court went beyond both historic and contemporary American authorization to examine the statute books of other civilized nations to support its holding that expatriation was cruel and unusual. "The civilized nations of the world are in virtual unanimity," it said, "that statelessness is not to be imposed as punishment for crime." Id. at IO2.

${ }^{33}$ Justice Frankfurter provided the deciding fifth vote allowing the state of Louisiana to proceed with a second electrocution after the first had failed, arguing that a second electrocution would not offend standards of decency generally held by the public. Louisiana ex rel. Francis v. Resweber, 329 U.S. 459, 47I (r947) (concurring opinion); see note 28 supre. See also Robinson v. California, 370 U.S. 660, 666 (I962); Weems v. United States, 2I7 U.S. 349, 378 (I9I0).

${ }^{34}$ Trop v. Dulles, 356 U.S. 86, I02 (I958); Weems v. United States, 2 I7 U.S. 349 (I9I0); see note 32 supra. 
was said to conflict with moral precepts "universally" held. ${ }^{35}$ The closest the Court has come to applying these criteria to capital punishment is in dictum offered by four justices in Trop v. Dulles, stating that "the death penalty has been employed throughout our history, and, in a day when it is still widely accepted, it cannot be said to violate the constitutional concept of cruelty." 36

Were these three criteria of the prevailing standards of decency the final tests of constitutionality under the eighth amendment, the death penalty would probably survive constitutional scrutiny. If long usage of a penalty is determinative of its constitutionality, capital punishment would be permissible because it has been employed in America since the colonial years, although with decreasing frequency. Similarly, if the eighth amendment condemns only punishments which are on the statute books of almost no jurisdiction other than the one before the Court, the death penalty, of course, could not be declared unconstitutional. Thirty-eight states, ${ }^{37}$ the federal government, and several other "civilized" countries ${ }^{38}$ still authorize execution, although there has been a trend toward abolition. And the American people are still divided on capital punishment. Fewer support the death penalty than in the early I950's, but about half of the public now tells opinion pollsters that they approve the penalty. ${ }^{39}$

${ }^{35}$ Robinson v. California, 370 U.S. 660, 666 (Ig62):

${ }^{36} 356$ U.S. at 99 (plurality opinion).

${ }^{37}$ For a listing of the crimes for which capital punishment is authorized in each of the thirty-eight states, see Brief for the N.A.A.C.P. Legal Defense and Educational Fund et al., Appendix A, Boykin v. Alabama, 395 U.S. 238 (Ig69).

${ }^{38}$ See Departament of Economic and Sociat Affatrs, Capital Punismanent 5-7 (United Nations Ig67).

${ }^{39}$ Public support for capital punishment as measured by opinion polls has been erratic, but generally declining, in the last two decades. In $1953,63 \%$ indicated approval of the death penalty; in $1958,42 \%$; in $1960,51 \%$; in $1965,45 \%$; in $1966,38-42 \%$; and in February, $1969,51 \%$. See American Institute of Public Opinion, Public Opinion and the Death Penalty, in The DeAtr Penatty in Amizrica 236-4I (H. Bedau ed. I964); CacIforNIA Note at I337; N.Y. Times, Feb. I6, I969, $\S I$, at 47 , col. I. It is interesting, however, that very few people apparently favor the death penalty for crimes other than murder. A recent Gallup poll found that although most of those interviewed favored a crackdown on airplane hijackers, bombers, and inciters of riots, $6 \%$ or fewer specified death as the proper punishment for these crimes. Boston Globe, Apr. 23, I970, at 15, col. 8.

The significant factor for constitutional purposes is the long range trend in opinion, not short range fluctuations. Often during crises in which the fear of crime is particularly intense, the public may temporarily favor harsh crime control measures at the expense of constitutional protections. It is the purpose of the Constitution, however, to direct attention to long range considerations and gradually developing standards of decency. Were suddenly intense frustration with civil liberties to be determinative of constitutional protection, the whole Bill of Rights might be thrown sporadically into doubt. Nor should governments, responsible to the public though they are, bend to every current popular whim when funda- 
If the eighth amendment is to retain independent moral force, these tests are not and cannot be the final arbiters of constitutionality. The long usage of capital punishment referred to in Trop cannot be determinative. Three times the Court has declared punishments unconstitutional which had deep historical roots. ${ }^{40}$ The purpose of looking to the past usage of a punishment cannot be to tie the meaning of the clause to standards of decency that prevailed long ago. The purpose of an historical reference, rather, must be to provide a backstop should new and horrible penalties be devised. As the Court observed in Trop, any entirely new type of harsh punishment would be immediately "suspect." ${ }^{41}$ This can only be a preliminary, not a final, test of constitutionality.

Nor should constitutional protection depend upon virtually unanimous condemnation of the penalty at issue. Were wide acceptance-measured by statutory authorization or public opinion polls - enough to authorize a punishment, the clause would indeed be "drained of any independent integrity as a governing normative principle." Like no other constitutional provision, its only function would be to legitimize advances already made by the other departments and opinions already the conventional wisdom. It would forbid only extremely aberrant penalties. The framers cannot have intended so narrow a role for this basic guaranty of human rights. Like the test of historical usage, these tests of prevailing opinion can serve only a backstop function. Thus the three objective criteria of the evolving standards of decency are properly viewed only as threshold, rather than determinative, inquiries under the eighth amendment. The final test must lie elsewhere.

Robinson $v$. California, ${ }^{42}$ the most recent decision holding a punishment unconstitutional under the eighth amendment, suggests that the Court may now be ready to reject the approach underlying the Trop dictum. The punishment at issue was imposition of a criminal penalty for mere narcotics addiction. Such criminal penalties were both long used and widely accepted. ${ }^{43}$ Yet

mental rights are at stake. The government of Great Britain recently provided an example for all to follow when it refused to reinstitute capital punishment despite substantial public support for the death penalty.

${ }^{40}$ Robinson v. Califormia, 370 U.S. 660 (I962) ; Trop v. Dulles, 356 U.S. 86 (I958); Weems v. United States, 2I7 U.S. 349 (I9I0); see notes 3 I \& 32 sulpra.

${ }^{41} 356$ U.S. at roo.

42370 U.S. 660 (1962).

${ }^{43}$ Justice Douglas pointed out, concurring in Robinson, that "[s]ome states punish addiction, though most do not." 370 U.S. at 672 . Punishment of addicts was less widely authorized than the death penalty now is, but more so than any punishment theretofore struck down by the Court under the eighth amendment. 
the Court reasoned that narcotics addition is a disease like mental illness or leprosy, and that "in the light of contemporary human knowledge, a law which made a criminal offense of such a disease would doubtless be universally thought to be an infliction of cruel and unusual punishment in violation of the Eighth and Fourteenth Amendments." 44 The Court did not say that general public opinion actually did condemn the imposition of criminal penalties for narcotics addiction. Rather, it said that the public, if fully informed, would condemn it. In other words, the Court looked not to actual standards of decency prevailing in society, but to enlightened standards. ${ }^{45}$

The Robinson approach to the evolving standards of decency is suggestive of the unconstitutionality of the death penalty. Were capital punishment, like criminal punishment of narcotic addiction, better understood, prevailing moral standards might well condemn it. Indeed, it may be that public approval of the death penalty is dependent upon a hiding away of its grim reality. One may wonder, with Justice Bok, "Why is the State so ashamed of its process that it must kill at dead of night in an isolated place, and on an unnamed day?" ${ }^{46}$ Applying a test of enlightened opinion, we might conclude that "if people were to witness the decay of the waiting man, to hear his cries and watch his final struggles, they would be affronted in their consciences, and in their standards of human dignity and decency." ${ }^{47}$ The fact that

44370 U.S. at 666.

${ }^{45}$ See Repouville v. United States, I65 F.2d I52 (2d Cir. I947). Defining the requirement of "good moral character" for citizenship, the court, per Judge Learned Hand, made a rough judgment of "the moral feelings, now prevalent generally in this country." "Id. at I53. Judge Frank, dissenting, argued that the courts are essentially "ignorant" and "utterly helpless" when it comes to making. such rough assessments of popular opinion, and that the majority relied simply upon its "unchecked surmises." He argued that "the correct statutory test . . . is the attitude of our ethical leaders." Id. at I54. Cf. United States v. Rosenberg, I95 F.2d $583,608-09$ (I952) (Frank, J.).

The attitude of "ethical leaders" is not the only possbile test of enlightened standards of decency. The courts might also look to the attitudes of those who must actually apply death penalty provisions, for example. They are enlightened in the sense of having the fullest appreciation of the human impact of capital punishment. The death penalty might now fall under this test as well.

${ }^{46}$ C. BOK, STAR WORArWOOd I97 (I959).

47 G. GotmineB, Capital Punismurent 6 ( I967). However, the unfortunate fact is that at least a segment of the public probably would relish public executions. The Royal Commission on Capital Punishment noted that there are in England an "average of five applications a week for the post of hangman, and the craving that draws a crowd to the prison where a notorious murderer is being executed, reveal psychological qualities of a sort that no state would wish to foster in its citizens." Royal Commission Report on Capital Punishment, in R. DoNNELIY, J. Goldsten, \& R. Schwartz, Crummai LaW 336 (I962). 
very few individuals convicted of capital crimes are executed suggests that many of those who bear the responsibility for administering death penalty provisions - prosecutors, judges, jurors, clemency boards, and governors - may indeed be so affronted. ${ }^{48}$

\section{B. A Purposive Test of Constitutionality}

The Supreme Court's opinions under the cruel and unusual punishment clause have suggested not only the evolving standards of decency formula, but also a more purposive approach. "The basic concept underlying the Eighth Amendment," the Trop Court stated, "is nothing less than the dignity of man." 40 To protect that underlying value, the Court has interpreted the clause to forbid punishments which are "degrading" in their severity and "wantonly imposed." 50

This section will analyze the opinions applying tests of degrading and wantonly imposed punishment not as conclusive standards of constitutionality, but as the first steps in a more systematic approach to cruel and unusual punishment doctrine. It will argue that, in fact, the Court's dicta allowing the "mere extinguishment of life" 51 have now been undermined. Reasoning from precedent, it will show that the death penalty is, at the very least, highly suspect under the standards of degrading severity and wanton imposition. As such, the burden of justification is placed on the state, and capital punishment then fails the

${ }^{48}$ See pp. I791-92 infra. The Court has recently suggested that the jury must reflect the standards of decency protected by the eighth amendment:

[O]ne of the most important functions any jury can perform ... is to maintain a link between contemporary community values and the penal system - a link without which the determination of punishment could hardly reflect "the evolving standards of decency that mark the progress of a maturing society."

Witherspoon v. Tlinois, $39 \mathrm{x}$ U.S. 5IO, 5xg n.I5 (I968). The apparent reluctance of juries in capital prosecutions to impose the death penalty, then, may suggest that enlightened opinion - meaning the opinion of those with the most immediate appreciation of the death sentence - is increasingly opposed to capital punishment. For another interpretation of the Witherspoon comment, see A. BICKEL, THE SUPRENE COURT AND THE IDEA OF PROGResS 74-75 (1970).

${ }^{49} 356$ U.S. at 100.

${ }^{30}$ See pp. $1785-94$ infra.

${ }^{51}$ In re Kemmler, I36 U.S. 436,447 (I89o), quoted with approval in Louisiana ex rel. Francis v. Resweber, 329 U.S. 459,464 n.4 (x947): The precedental force of both Kemmler and Francis is limited by the fact that neither one specifically applied the cruel and unusual punishment clause. Rather, Kemmler was the first decision to hold that the clause was not applicable to the states; thus its discussion of the eighth amendment is strictly dictum. The Francis Court also applied only the fourteenth amendment due process clause, but it did assume, "without so deciding," that the eighth amendment protection was applicable and directed its discussion to the cruel and unusual punishment clause. 329 U.S. at 462. 
overriding test suggested by the Court under the eighth amendment: that condemning excessively severe punishment.

The application of purposive standards to establish the suspect nature of governmental action, thus shifting the burden of justification to the state, is familiar to constitutional adjudication. Under the free speech ${ }^{52}$ and free exercise of religion ${ }^{53}$ clauses of the first amendment, for example, the state is required to provide a "compelling" (rather than merely a "reasonable") justification for actions interfering with the self-expression of minority groups. It is the importance of the primary right that is infringed and the discriminatory impact of the infringement which shifts the burden of justification. The same approach, of course, is employed under the equal protection clause when the fundamental rights of certain disadvantaged minorities are curtailed..$^{54}$ The interest protected by the cruel and unusual punishment clause should not be taken as any less central than those protected by these other provisions of the Bill of Rights. The eighth amendment commands that the standards of dignity and fairness which protect citizens generally must also apply in some form to those convicted of crimes. So understood, the cruel and unusual punishment clause is a crucial part of the constitutional scheme. Its proscription of degrading severity and wanton imposition may be viewed as the indices of fundamentality and invidiousness which require a compelling justification from the state.

I. The Analogy to Torture: Extreme and Degrading Severity. - The two earliest Supreme Court decisions dealing with the cruel and unusual punishment clause sanctioned particular methods of administering the death penalty, shooting and electrocution. In both cases the Court interpreted the clause to reach only those methods of punishment similar to the tortures practiced during the Stuart reign in England, which the framers of the eighth amendment clearly intended to forbid. ${ }^{55}$ It stated that a cruel and unusual punishment is one that may be called an "atrocity" 56 or "something inhuman and barbarous" which in-

${ }^{52}$ See, e.g., NAACP v. Button, 37 I U.S. 4I5 (Ig63); NAACP v. Alabama ex rel. Patterson, 357 U.S. 449 (I958); De Jonge v. Oregon, 299 U.S. 353 (I937); The Supreme Court, 1968 Term, 83 HaRv. L. Rev. 7, 93-95 (I969).

${ }^{53}$ See Sherbert v. Verner, 374 U.S. 398 (1963).

${ }^{54}$ See Developments in the Law-Equal Protection, 82 HARv. L. REv. I065, II3I-32 (I969): The senior author set forth his view that, as a general principle of constitutional law, a "compelling" justification must be shown "where fundamental personal liberties are involved" in Griswold v. Connecticut, 38I U.S. 479, 497 (I965) (concurring opinion).

${ }^{55}$ On the intentions of the framers, see Granucci, "Nor Cruel and Unusual Punishments Inflicted:" The Original Meaning, 57 Carm. L. Rev. 839 (Ig6g).

${ }^{56}$ Wilkerson v. Utah, 99 U.S. 130, 135-36 (I878). 
flicts a "lingering death." 57 The examples of impermissible punishment cited were burning at the stake, crucifixion, and breaking on the wheel. ${ }^{58}$ Shooting and electrocution, by contrast, were thought to be relatively quick and painless techniques of execution. Implicit in the refusal to hold these methods unconstitutional was a failure to reject the death penalty itself. And, in In re Kemmler ${ }^{59}$ the Court, while holding that the eighth amendment was inapplicable, ${ }^{60}$ included dicta to the effect that the amendment did not prohibit the "mere extinguishment of life." Only once since 1890 has the Court cited that dicta with approval, concluding that only "execution by the state in a cruel manner" 61 is prohibited.

Expansion of the constitutional proscription beyond physical torture began in Weems $v$. United States, ${ }^{62}$ decided in 1910. There, the Court held unconstitutional a sentence of fifteen years at "hard and painful labor" in ankle chains and lifetime civil disabilities imposed for the falsification of a public record in the Philippines Territory. The Court held this penalty, cadena temporal, unconstitutionally disproportionate to so minor a crime; but it suggested also that the punishment in itself was at least suspect under eighth amendment standards of cruelty. "No circumstance of degradation is omitted," it observed. "It may be that even the cruelty of pain is not omitted." ${ }^{3}$ "The eighth amendment was not to be limited to concern with such extraordinary tortures as burning at the stake or boiling in oil.

An even more expansive interpretation of the eighth amendment's cruelty test was applied in Trop $v$. Dulles, ${ }^{04}$ the one case in which the Court has declared a punishment to be cruel and unusual without regard to the seriousness of the crime. There the Court held that the punishment of expatriation violates the eighth amendment. It moved beyond concern with extreme, lingering physical pain to the mere possibility of such pain and then to

${ }^{57}$ In re Kemmler, 136 U.S. 436, 447 (1890).

${ }^{58} I d$. at 446.

${ }^{59} x_{3} 6$ U.S. 436 (1890).

${ }^{60}$ See note 48 supra.

${ }^{61}$ Louisiana ex rel. Francis v. Resweber, 329 U.S. 459,463 (I947).

62 2I7 U.S. 349 (I9I0). The Weems majority explicitly rejected the argument that the scope of the cruel and unusual punishment clause was limited to torture. Id. at $37 \mathrm{I}-73$.

${ }^{63} I d$. at 366 .

${ }^{84} 356$ U.S. 86 (1958). In Perez v. Brownell, 356 U.S. 44 (I958), the Court allowed expatriation under another section of the federal statute involved in Trop. It found that section to be regulatory rather than penal, thus rendering the eighth amendment inapplicable. Later, in Kennedy v. Mendoza-Martinez, 372 U.S. I44 (1963), the Court struck down another expatriation provision under a penal section of the statute. But rather than reach the eighth amendment issue, it held that the requirements of procedural due process were not satisfied. 
similar psychological distress; and, beyond that, it emphasized the sheer enormity of the punishment. An expatriate is potentially subject to untold physical abuse, the Court said, and he is also subjected to "a fate of ever-increasing fear and distress." 05 Justice Brennan's concurrence, which was necessary for a majority, commented that " $[t]$ he uncertainty, and the consequent psychological hurt, which must accompany one who becomes an outcast in his own land must be reckoned a substantial factor in the ultimate judgment." ${ }^{60}$ Furthermore, the penalty of expatriation, the Court said, "is a form of punishment more primitive than torture, for it destroys for the individual the political existence that was centuries in the development .... His very existence is at the sufferance of the country in which he happens to find himself." 67

Justice Frankfurter asked in dissent: "Is constitutional dialectic so empty of reason that it can be seriously urged that loss of citizenship is a fate worse than death?" 68 There can be only one answer to that rhetorical question. The factors relevant to the plurality decision in Trop are even more applicable in the context of capital punishment. The mental torture of life on death row has been well documented in recent years. ${ }^{69}$ The high incidence of insanity among inmates sentenced to death was in fact noted in an opinion by Justice Frankfurter. ${ }^{70}$ Surely the fear and distress of a man who knows he is about to be killed is at least as great as that of an expatriate. Similarly, the degree of physical pain involved in all available methods of execution is open to question. Death by electrocution, lethal gas, and hanging is often by no means instantaneous and may be extraordinarily painful." The Kemmler Court's approval of the "mere extinguishment of life" by electrocution thus may have rested on an

${ }^{65}$ Trop v. Dulles, 356 U.S. 86 , I02 (I958).

${ }^{60} I d$. at IrI. Justice Brennan's concurrence rested not on the eighth amendment, but on the lack of a reasonable relation to the Congress' power to deal with desertion.

${ }^{67} I d$. at Ior.

${ }^{68} I d$. at 525 .

${ }^{69}$ For personal accounts of the mental torture of life on death row, see $R$. Hammer, Between Life and Death (rg69); E. Smith, Brief Aganist Death (I968). See also B. Eshelman, Death Row Chapratn (I962); B. Wrtherspoon, DEATH ROW (I968).

${ }^{70}$ Solesbee v. Balkcom, 339 U.S. 9, I4 (I950) (Frankfurter, J., dissenting).

${ }^{71}$ See CaLIfornta Note at I338-43; Gottlieb, Testing the Death Penalty, 34 S. CAL. L. Rev. 268, 273-74 (I96r). In Louisiana ex rel. Francis v. Resweber, 329 U.S. $459,480 \mathrm{n.2}$ (1947), the dissent quoted an eyewitness description of the first, abortive electrocution of Willie Francis: "Then the electrocutioner turned on the switch and when he did Willie Francis' lips puffed out and he groaned and jumped so that the chair came off the floor. Apparently the switch was turned on twice and then the condemned man yelled: "Take it off. Let me breath." '" 
unrealistic factual understanding. Moreover, consideration of the enormity of the penalty suggested in Trop - jeopardizing one's "very existence" - can only apply with more force to capital punishment.

Trop suggests the cruelty of the death penalty, but only by comparison. The Trop plurality did not attempt to articulate a principle limiting the scope of eighth amendment cruelty. The Court today might hesitate to extend Trop any further for fear that the extension would not stop. Life imprisonment, for example, destroys an individual's "political existence" nearly as much as does expatriation; indeed, an expatriate out of prison clearly has far more opportunity to enjoy the advantages of a free society than the inmate. Even if their levels of psychological distress could be reliably compared, it is not at all certain whose would be greater. There is, however, a principle latent in the Trop decision which can limit its application - as well as explain the Court's comparison of expatriation to the ancient Stuart tortures which concerned the framers of the eighth amendment. It has to do not with the component of physical or psychological pain (the reference to such pain is surely the least convincing aspect of the Trop opinion), but with the sheer enormity of the punishment. An expatriate, the Court said, is deprived of his "right to have rights." "2 Similarly, an executed convict is deprived of his "right to have rights" - indeed, in some cases, those rights relating to the propriety of his conviction. As standards of due process and fundamental fairness develop and are sometimes retroactively applied, a conviction that would survive legal attack one year may fall the next year. But when convictions result in application of the death penalty, they cannot be reversed and vacated; the convict may be legally innocent and would go free but for the finality of his sentence. ${ }^{73}$ By contrast, one imprisoned even for life retains certain "rights;" he is not divested of all societal protection. In Justice Brennan's term, a man sent to his death is made a total "outcast." He is degraded below the minimal status of man and citizen. The ties of society to the individual that are severed by the death penalty, as by brutal torture, are those which are most essential to a system of mutual restraint, obligation and respect for human dignity.

${ }^{72} 356$ U.S. at I02.

${ }^{73}$ Compare, for example, the cases of Williams v. Georgia, 349 U.S. 375 (1955), and Fay v. Noia, 372 U.S. 39 I (I963). In each case, the accused was convicted of first degree murder by a process which was not deemed unconstitutional at the time it was conducted; in each case the process was subsequently declared unconstitutional; in each case the acused did not properly raise constitutional objections to the process. The only difference was that Williams was sentenced to death and executed while Fay was sentenced to life imprisonment. Fay is now free; so probably would Williams be were it not for his death sentence. 
2. Unusualness: Irregularly and Anomalously Imposed Punishment. - A recent study of the origins of the ban on cruel and unusual punishment has demonstrated that while fear of torture was the central concern of the framers of the eighth amendment, its English background indicates that the concern for regularity and generality in the imposition of severe punishment also underlies the clause. ${ }^{74}$ It was this concern which bred the mention of "unusual" punishment. ${ }^{75}$ Although the constitutional meaning of unusualness has never been clarified and has for the most part not been distinguished from the meaning of cruelty, ${ }^{76}$ there is some basis in the Supreme Court precedent for a principled proscription of anomaly and irregularity in the application of harsh penalties. ${ }^{77}$

Perhaps the more ordinary meaning of unusualness relates to the infrequency with which a punishment is imposed. The Supreme Court's attention to usage outside the jurisdiction before it in Wilkerson, Weems, and Trop ${ }^{78}$ may be read not only as a measurement of the evolving standards of decency, but also as a reference to the anomaly of the punishments in question. Neither the cadena temporal in Weems nor expatriation in Trop was authorized elsewhere. When an individual is singled out because of an accident of geography for unusually severe treatment, it seems particularly cruel. In both Weems and Trop, the punishments were anomolous largely on a geographical scale. But Trop

${ }^{74}$ The incident which prompted inclusion of the cruel and unusual punishment protection in the 1688 Bill of Rights was the prosecution and punishment of Titus Oates in I685. Oates was not tortured. The offensive aspects of his punishment at the time were the irregular process by which it was imposed and the fact that Oates was singled out for a sort of treatment not previously applied to others similarly situated. The irregularity and anomaly of Oates' treatment was extreme. His punishment was neither authorized by statute nor within the jurisdiction of the court to impose. Granucci, supra note 55, at 857-59. American courts have sometimes seemed to adopt a very restricted view of irregularity and anomalyasserting that a punishment authorized by statute cannot be cruel and unusual. E.g., Martin v. United States, 3r7 F.2d 753, 755 (9th Cir. 1963).

${ }^{75}$ The only recorded use of the word "unusual" in conjunction with "cruel" leading up to the drafting of the 1688 Bill of Rights was in reference to the Titus Oates affair. Granucci, supra note 55, at 859-60.

78 'Whether the word 'unusual' has any qualitative meaning different from 'cruel' is not clear. On the few occasions this Court has had to consider the meaning of the phrase, precise distinctions between cruelty and unusualness do not seem to have been drawn." Trop v. Dulles, 356 U.S. 86, I00 $\mathrm{n.32}$ (I958).

${ }^{77}$ Of course, anomaly and irregularity alone would be insufficient to declare a punishment unconstitutional. Approving electrocution in In re Kemmler, the Court recognized that New York was alone in using that method of execution; but it pointed out that electrocution was thought to be a less painful method than any other in use elsewhere. I36 U.S. at 447. Although it was unusual, the method was not considered cruel, and the eighth amendment must require at least a finding of cruelty before it will condemn a punishment.

${ }^{78}$ See notes 3 I \& 32 supra. 
also hints that a punishment might be cruelly unusual if individuals convicted of the same crime in the same jurisdiction are rarely subjected to it. The Court specifically noted that of 2 I,000 soldiers and airmen convicted of desertion during World War II, only a third were deprived of their citizenship. ${ }^{79}$ Although imposition of expatriation for desertion was not so anomalous as to be "unusual," 80 it may be significant that the Court looked not only to the prevalence of the punishment's statutory authorization, but also its actual administration.

Infrequency of imposition of a particular penalty cannot by itself offend constitutional values if there is some good reason for singling out the class of individuals on whom it is inflicted. The offensive aspect of singling out individuals along geographical lines is the probability that there is no good reason for the anomalous treatment. Similarly, anomalous imposition of a very harsh punishment within a particular jurisdiction may rest on no reasonable classification. A penalty therefore should be considered "unusually" imposed if it is administered arbitrarily or discriminatorily.

The process by which the penalty of expatriation was imposed was unusual in that sense. The Trop plurality pointed out that the authorizing statute gave "the military authorities complete discretion to decide who among convicted deserters shall continue to be Americans and who shall be stateless." ${ }^{81}$ Standardless discretion combined with the evidence that the punishment of expatriation was relatively rarely imposed does raise the probability that those actually expatriated were treated unusually. Although the Court did not explicitly make this connection to cruel and unusual punishment doctrine, it must have felt a special responsibility to the convicted deserters singled out for such drastic punishment. When the legislative branch leaves the imposition of an extraordinary penalty to virtually unguided administrative discretion, it signifies an intention to wash its hands of the matter. So long as relatively few people convicted of the crime are actually subjected to the punishment, it is unlikely that the legislators will

${ }^{79} 356$ U.S. at 9 I. The Trop plurality made this reference to the actual imposition of expatriation before its discussion of the eighth amendment. Thus it did not explicitly assign constitutional significance to the fact that only one-third of deserters were expatriated.

${ }^{80}$ The Supreme Court has held that the eighth amendment does not require perfect equality in the punishment of similar crimes. Badders v. United States, 240 U.S. 39I (IgI6) ("Undue leniency in one case does not transform a reasonable punishment in another case to a cruel one"). But a proscription of anomalous punishment does not amount to a requirement of perfect equality. Although the eighth amendment does not require equality, it does require some degree of generality.

${ }^{81}$ Id. at go. 
take notice. Those who lose the game of chance can only turn to the courts.

The Court more explicitly recognized the notion of regularity as an eighth amendment interest in Louisiana ex rel. Francis $v$. Resweber. ${ }^{82}$ It suggested that the proscription of unusual punishment extends to "wanton" as well as arbitrary imposition of severe penalties. Focusing on the manner in which a first abortive attempt to electrocute Francis had been conducted, it spoke of the "[p]rohibition against the wanton infliction of pain [that] has come into our law from the Bill of Rights of $r 688 . "{ }^{83}$ In the Court's opinion, Francis had not been subjected to the wanton infliction of pain; the extra pain he suffered was unavoidably accidental. ${ }^{84}$ The Court implicitly assumed that his death sentence itself was not wantonly imposed. The validity of that assumption, however, may now be called into question.

Popular uneasiness with official execution and concern for the individualization of punishment has led in this century to an emphasis on discretionary imposition of the death penalty. Most states which once made capital punishment mandatory for certain crimes have now provided alternate penalties. ${ }^{85}$ Similarly, degrees of murder have been instituted so as to avoid execution in all cases. ${ }^{86}$ The result of this humanitarian effort, however, has been to make the process by which the death penalty is imposed haphazard to say the least.

Imposition of the death penalty is now almost as rare as the cadena temporal. From I960 to I964, there were $\mathrm{x} 8 \mathrm{I}$ executions in the United States; since I965, there have been only ten executions. ${ }^{87}$ In the last three years, there have been none. ${ }^{88}$ Of course, the figures on actual executions are affected by current stays of execution and postconviction proceedings, and almost five hundred individuals are now on death row. But even in the unlikely and tragic event that all of those five hundred men are in fact killed, there are thousands more who were convicted of commit-

82329 U.S. 459 (I947).

83329 U.S. at 463 .

84

The fact that an unforeseeable accident prevented the prompt consummation of the sentence cannot, it seems to us, add an element of cruelty to a subsequent execution. . . . The situation of the unfortunate victim of this accident is just as though he had suffered the identical amount of mental anguish and physical pain in any other occurence, such as, for example, a fire in the cell block.

Id. at 464 .

85 See The Death Penatty in Amrerica 27-30 (H. Bedau ed. I964).

${ }^{80}$ See id. at $23-27$.

87 U.S. Bureau of Prisons, Executions: I930-r967, National Prisoner StaTISTICs BULL. No. 42 , June, I968, at 7 .

${ }^{88}$ See note I supra. 
ting the same acts but who were not sentenced to death. The extreme rarity with which applicable death penalty provisions are put to use raises a strong inference of arbitrariness. It is difficult to conceive of a rational standard of classification which could explain the extraordinary infrequency of execution. Furthermore, when the evidence of extreme rarity is viewed in the context of the standardless discretion that in fact governs imposition of capital punishment, the inference of arbitrariness is stronger. Surveying the actual impact of the death penalty, former Attorney General Ramsey Clark has commented that only a "small and capricious selection of offenders have been put to death. Most persons convicted of the same crimes have been imprisoned." 89

Most commentators describe the imposition of the death penalty as not only haphazard and capricious, but also discriminatory. The President's Commission on Law Enforcement and Administration of Justice, for example, stated that "there is evidence that the imposition of the death sentence and the exercise of dispensing power by the courts and the executive follow discriminatory patterns. The death sentence is disproportionately imposed and carried out on the poor, the Negro, and the members of unpopular groups." ${ }^{90}$ The impact of the death penalty is demonstrably greatest among disadvantaged minorities. ${ }^{01}$

${ }^{89}$ Statement by Attorney General Clark before the Subcommittee of Criminal Laws and Procedures of the Senate Judiciary Committee, July 2, I968, Department of Justice Release 2. See also C. DUFFy \& A. HIRSHBERG, 88 MEN AND 2 WOMEN 254-55 (I962). A recent study of penalty juries in California has indicated that it would be inaccurate to characterize their decisionmaking as entirely random. Some factors - proper and improper ones - affect decisionmaking with some degree of consistency. Special Issue, A Study of the California Penalty Jury in First-Degree-Murder Cases, 2I StaN. L. REv. I297, I4I9 (I969). The existence of a general pattern, however, does not amount to regular, standardized decisionmaking.

A case now before the Supreme Court raises the argument that standardless jury discretion for capital crimes is a denial of due process. Maxwell v. Bishop, 398 F.2d 138 (8th Cir.) (Blackmun, J.), cert. granted, 393 U.S. 997 (I968).

${ }^{\circ 0}$ The President's Compmission on Law Enforcement and Administration of Justice, The Challenge of Crime in a Free Society 143 (I967). See also H. Matrick, The Unexaminned Deatr 5, I7 (2d ed. I966); Bedau, A Social Philosopher Looks at the Death Penalty, I23 ANc. J. PsychIATRX 136x, r362 (1967); Hartung, Trends in the Use of Capital Punishment, 284 ANNaIs 8, I4-I7 (I952).

${ }^{91}$ Between $x 93 \circ$ and 1967 , of 3,859 individuals executed countrywide, over half were nonwhite; almost $90 \%$ of those executed for rape were nonwhite. NATroNaI Prisoner Statistics, supra note 87 , at 7 . Of 2,306 individuals executed in the South during the same period, $72 \%$ were black. Id. at $\mathrm{xr}$. Of the individuals on death row in $I 967,55 \%$ were nonwhite. Id. at 22 . One commentator has summarized the social and economic impact of the death penalty as follows: "[T]he death penalty .... almost always hits the little man, who is not only poor in material possessions but in background, education, and mental capacity as well." C. DUFFY \& A. HTRSHBERG, supra note 89 , at 256 . 
There are studies showing that this impact is disproportionate - to be explained only by racial, economic, or social discrimination. ${ }^{22}$ The inference that such is the case must be strong in a society marked by widespread prejudice. Unstructured discretion allows factors such as racial bias to influence judgments concerning the "individualization" of punishment. Evaluations of social worth naturally affect evaluations of individual culpability and capacity for reform.

Even if the Supreme Court decides in the pending case of Maxwell v. Bishop ${ }^{03}$ that legislatures must provide standards for application of the death penalty, it is very unlikely that the essentially arbitrary and discriminatory imposition of capital punishment can be halted. There is too much play in the joints of the criminal process. Prosecutorial discretion at one end of the process and executive clemency discretion at the other may be enough to preserve the capricious character of capital punishment. Restrained by standards for sentencing, juries may simply

${ }^{22}$ Some evidence of racial discrimination has been found in the following limited studies. Bedau, Death Sentences in New Jersey I907-xg60, Ig RUTGERs L. REV. I, I8-2I, 52-53 (I964); Garfinkel, Research Note on Inter- and Intra-Racial Homicides, 27 SOCIAL ForCes 369 (I949); Johnson, Selective Factors in Capital Punishment, 36 Soczax Forces I65 (I957); Johnson, The Negro and Crime, 2I7 Annals 93 (I94I); Wolfgang, Kelly \& Nolde, Comparison of the Executed and the Commuted Among Admissions to Death Row, 53 J. CRTM. L.C. \& P.S. 30r (I962) (dealing primarily with executive clemency).

Most recently, Professor Wolfgang has done a statistical study of sentencing for rape in Arkansas and found a "twenty-year pattern of racially differential sentencing pursuant to which Negro defendants convicted of rape - and particularly Negro defendants convicted of the rape of white complainants - were disproportionately frequently sentenced to die. Exhaustive efforts to explain the sentencing differentials on other grounds than race failed ...." Brief for the NAACP Legal Defense and Educational Fund, Inc. et al. as Amici Curiae at 53, Boykin v. Alabama, 395 U.S. 238 ( $(969)$. Professor Wolfgang's findings were presented in Maxwell v. Bishop, 398 F.2d I38 (8th Cir. I968), to support a claim of denial of equal protection. They were held insufficient to establish the claim by both the district and circuit courts, and are now before the Supreme Court. The circuit court objected, for example, that the findings were not recent enough (based on 5965 research) or focused specifically enough on the county in question. Id. at I4I-48. The court, however, did state that "[w]e do not say that there is no ground for suspicion that the death penalty for rape may have been discriminatorily applied over the decades in that large area of states whose statutes provide for it. There are recognizable indicators of this." Id. at $\mathrm{I}_{48}$. The difficulty of conducting a comprehensive and ultimately convincing statistical study is discussed in Brief for the NAACP, supra at 53-55; The Deatr Penalty In Amertca 4II-I3 (H. Bedau ed. $x 964)$.

The Stanford Lave Review study of California penalty juries in first-degree murder cases found racial prejudice to be an apparently minimal factor in the decision to inflict the death penalty. But it found that more general discrimination against blue-collar individuals was influential. California Penalty Jury, supra note 89 , at $1419,142 I$.

${ }^{83} 393$ U.S. 997 (Ig68) (granting certiorari). 
decline to convict certain people of capital crimes, but not others. As long as class and racial prejudice is prevalent, imposition of the death penalty probably will not simply be random but discriminatory. Perhaps there can be no perfectly regular process by which punishments can be imposed. But if the choice is between imperfect administration of capital punishment and abolition of capital punishment, constitutional values weigh heavily in favor of the latter.

3. Excessive Severity. - In the preceding two sections we have shown that the death penalty is suspect under standards of both cruelty and unusualness. Its infrequent and discriminatory application provides a special justification for constitutional intervention. When any governmental action infringing primary rights is applied in this manner, the ordinary political process cannot always be depended upon to redress the grievance. Though minority groups are, fortunately, increasing their political power, isolated members of disadvantaged minorities still have little political influence. Their protection must be derived from the Constitution. At the very least, a heavy burden must be on the state to justify the imposition of an extraordinary severe punishment whose impact is so erratic. If the state cannot provide compelling justification for the severity of the penalty, it should be constitutionally required to substitute a less severe one.

In Rudolph v. Alabama, ${ }^{94}$ the senior author suggested that two tests under a principle of excessive severity should be applied to the death penalty when imposed for rape. Those tests should also be applied to capital punishment per se. The death penalty should be held unconstitutional if (a) it produces hardship disproportionately greater than the harm it seeks to prevent, or (b) a less severe punishment could as effectively achieve the permissible ends of punishment.

The purpose behind the excessive severity principle is in a sense utilitarian; but it is surely related to the concept of decency, which is usually said to underlie the clause. ${ }^{95}$ In an enlightened age, it is hardly far-fetched to say that any excessive infliction of

${ }^{94} 375$ U.S. 889 (1963) (dissenting to denial of certiorari).

${ }^{95}$ Professor Packer has criticized the senior author's Rudolph opinion on the ground that the eighth amendment "speaks to the issue of decency, not rationality." Packer, supra note 5, at 1076, I079. Separation of the two issues, however, is artificial. We will demonstrate in this section that the Court has at least suggested an interpretation of eighth amendment decency which comprehends a ban on unnecessary infliction of severe pain. Moreover, it is very much part of our moral tradition now to include utilitarian cost-benefit analysis as a part of normative values such as justice; there is no clear line between morality and rationality. See, e.g., Mill, Utilitarianism, in The UTHITAarians 446-70 (Anchor ed. 1961). Professor Packer seems to want to limit the eighth amendment to a shock-theconscience type formula, but our conscience surely is informed by our reasoned calculation of costs and benefits. 
hardship degrades its object and is "indecent." Support for the principle may be found in Supreme Court precedent. In Wilkerson v. Utah, ${ }^{96}$ its first cruel and unusual punishment decision involving death by shooting, the Court said that torture was obnoxious in that it imposed "unnecessary cruelty." 97 The Court was at that time focusing only on methods of punishment, and it found that shooting inflicted no pain that was not necessary to carry out the death sentence. Under such a narrow principle, reiterated in Francis, ${ }^{98}$ the eighth amendment might simply require that the most advanced - quickest and least painful technique of execution be employed.99

In I892, however, an expansion of the "unnecessary cruelty" principle began. In O'Neil $v$. Vermont, ${ }^{100}$ Justice Field argued in dissent that imprisonment for I9,9I4 days following conviction for 307 separate offenses of selling intoxicating liquor was unconstitutional. The principle underlying the eighth amendment, he said, was a proscription of "excessive" punishment in this case, excessive in view of the crime for which it was imposed. In the next cruel and unusual punishment case, Weems v. United States, ${ }^{101}$ the Court adopted Justice Field's approach. Again, it was the extent of punishment rather than the method of its effectuation that was at issue. Holding that it was excessive when imposed for the crime of falsifying a public record, the Court stated that "[ $t]$ he State thereby suffers nothing and loses no power. The purpose of punishment is fulfilled, crime is repressed by penalties of just, not tormenting, severity, its repetition is prevented, and hope is given for the reformation of the criminal." ${ }^{102}$ Thus the principle of excessiveness in Weems was applied both to the proportionality between crime and punishment and to the severity of penalty necessary to achieve the proper purposes of punishment. In 1958 and I962, respectively, Justice Brennan and Justice Douglas concurring in cruel and unusual punishment decisions again emphasized both standards of excessive severity. ${ }^{103}$

${ }^{80} 99$ U.S. I30 ( 1878$)$.

${ }^{87} \mathrm{Id}$. at $\mathrm{I} 36$.

08 "The traditional humanity of modern Anglo-American law forbids the infliction of unnecessary pain in the execution of the death sentence." 329 U.S. 459, 463 ( 1947 ).

${ }^{90}$ England's Royal Commission on Capital Punishment evaluated electrocution, hanging, lethal gas, and lethal injection by reference to these criteria. It found distinctions among the various methods very difficult to establish. See R. Dow-

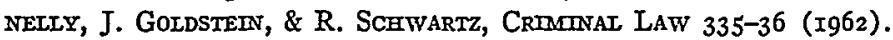

${ }^{100}$ I44 U.S. $323,339-4 I, 364-65$ (I892).

101217 U.S. 349 (I9I0).

${ }^{102} I d$. at $38 x$.

${ }^{103}$ Robinson v. California, 370 U.S. 660, 677 (Ig62) (Douglas, J., concurring); Trop v. Dulles, 356 U.S. 86, III-I2 (I958) (Brennan, J., concurring). 
The disproportionate hardship principle clearly invalidates some grossly disproportionate applications of capital punishment. The harm done by simple unarmed robbery or by any economic crime, for example, is surely not equal to the hardship that would be imposed by execution of the robber. Even if the deterrence of future robberies that might be achieved by execution of convicted robbers is taken into account, a society that values human life over material possessions cannot find capital punishment for economic crimes to be justified by the principle of proportionality.

Even when the death penalty is imposed for the taking or endangering of life, its constitutionality must depend upon the state's ability to demonstrate a compelling justification for using it instead of a less severe penalty. ${ }^{104}$ Crucial to application of this test, of course, is clear understanding of what are the permissible ends of criminal punishment. It has been suggested that if retribution is such an end, capital punishment can be justified. The effectiveness of a punishment in achieving the purpose of retribution or revenue is probably impossible to assess. It is primal community passion that provides the standard. There may be no way to determine whether execution alone can satisfy that passion, or whether any severe penalty which a society chooses as its most extreme punishment could do as well. Thus it probably must be conceded that capital punishment may serve the end of retribution and that it cannot be known whether another less severe punishment would serve it as effectively. Deterrence, isolation and rehabilitation, on the other hand, are somewhat more precise notions. It cannot be shown that the death penalty serves them any more effectively than, for example, life imprisonment. Capital punishment obviously does not achieve rehabilitation at all; indeed, it is totally destructive of that purpose. It serves the isolative function very effectively. But, assuming that our jails are secure and that inmates are not released prematurely, life imprisonment serves that end no less effectively. And, at least for the present, it may be concluded that statistical study has shown that it cannot be proved that the death penalty deters crime any more effectively than life imprisonment. ${ }^{105}$ Thus the argument for the constitutionality of capital punishment based on the excessive severity principle must come down to the problematic as-

${ }^{104} \mathrm{~A}$ compelling interest test is also suggested in CaIIFORNIA Note at 1353.

105 Almost all of the evidence collected in statistical studies comparing jurisdictions with and without capital punishment and comparing a single jurisdiction before and after abolition of capital punishment indicates that the death penalty has no significant impact on the crime rate. See The Deatr Penalty In America 258-332 (H. Bedau ed. I964). Uncertainty is due to the fact that it is very difficult to be sure that all relevant variables other than capital punishment can be eliminated. See Cariforiala Note at I275-92. 
sertion that no less severe punishment can achieve the retributive end as well as execution.

That argument should fail under the cruel and unusual punishment clause. Inherent in the logic of a ban on cruel and unusual punishment is the requirement that a penalty serve some other end besides retribution more effectively than any other less severe penalty. ${ }^{108}$ Otherwise, the most horrible tortures might be permissible. Boiling in oil, for example, cannot be said to be equalled by a less harsh punishment in its capacity to serve the end of revenge. If it were not required to pass some test other than the retributive one, it would not be prohibited under that test.

The only constitutional defense of the death penalty under the excessive severity principle, then, concerns the purpose of deterrence. Although it cannot be proven that the death penalty is any more effective a deterrent than life imprisonment, neither can it be shown with certainty that it is less effective. ${ }^{107}$ Evaluation of this statistical evidence is perfectly appropriate for the courts. Scholarly investigation has reached such a stage that the peculiarly legislative or executive capacity for fact-gathering is not crucial. Indeed, the courts may be able to give a more detached consideration to this data than can the other branches of government. Nevertheless, customary deference to legislative judgments on complicated issues of fact might be thought to require that the Court allow capital punishment to stand. However, when the burden of justification is shifted to the state after the death penalty is found suspect under the standards of cruelty and unusualness, the unconstitutionality of capital punishment is persuasively established. Since the state cannot sustain its burden by showing compelling reason to believe that a legitimate purpose of the criminal law is more effectively served by the death penalty than by a less severe punishment, capital punishment should be held unconstitutional.

The conclusion to be drawn from this analysis of cruel and unusual punishment doctrine is that the clause has generated a set of principles which, when coupled systematically with traditional

${ }^{108}$ It has been argued that the cruel and unusual punishment clause prohibits retribution as a purpose of criminal punishment altogether. CALIFORNIA Note at 1349-54. The argument being made here is narrower. On several occasions, however, members of the Court have seemed to disapprove retribution as an end of punishment, if only by failing to include it in a listing of such ends. E.g., Rudolph v. Alabama, 375 U.S. 889, 89I (Ig63) (dissenting opinion); Trop v. Dulles, 356 U.S. 86 (r958) (concurring opinion); Williams v. New York, 337 U.S. 24I, 248 (I949).

${ }^{107}$ See note IOI supra. 
modes of adjudication applied to the protection of other primary rights, condemn the death penalty as unconstitutional. These principles are both implicit in precedent and immediately compelling.

\section{Supreme Court Avoidance of Decision}

If the Court's failure to apply the principles of cruel and unusual punishment to the death penalty is to be justified, it must be primarily in terms of the Court's peculiar institutional position. The preceding part of this article has demonstrated that the nature of established doctrine under the clause provides no justification. In this part several institutional considerations often thought to counsel restraint will be analyzed in the context of capital punishment.

\section{A. Substance and Procedure}

The Supreme Court's failure to decide the constitutionality of the death penalty is not accidental. In the last few years, it has refused several times to hear cases raising the cruel and unusual punishment claim. ${ }^{108}$ Finally, during the r968 Term, the issue was extensively briefed and argued in Boykin v. Alabama. ${ }^{100}$ The case presented the strongest possible setting for a cruel and unusual punishment holding. Boykin, a Negro, had been sentenced to death for simple robbery; Alabama is the only state to allow capital punishment for such a crime. The petitioner argued not only that the death penalty was per se cruel and unusual, but also offered the Court a narrower theory - that at the least it is impermissible to take a life for a crime that did not involve a killing or even a serious injury. ${ }^{110}$ The decision in the case, however, reversed Boykin's conviction on procedural grounds, making no reference to the constitutionality of the death penalty.

This is not to argue that the Court was mistaken in reversing the conviction on procedural grounds. But the Boykin decision is illustrative of a more general theme in the Court's treatment of capital punishment cases - and of criminal cases generally. It has been deeply concerned with the area of the criminal law. But for the most part that concern has related largely to matters of fair procedure.

Some tension has arisen between the Court's preference for procedural reform and its apparently growing aversion to the

${ }^{108}$ E.g., Alvarez v. Nebraska, 393 U.S. 823 (I968); Craig v. Florida, 383 U.S. 959 (Ig66); Swain v. Alabama, 382 U.S. 944 (I965) (Douglas, J., dissented); $c f$. Rudolph v. Alabama, 375 U.S. 889 (I 963 ).

${ }_{109} 395$ U.S. 238 (I969).

${ }^{110}$ Brief for Petitioner at 8-24, Boykin v. Alabama, 395 U.S. 238 (I969). The state of Alabama did recently execute a man for robbery - specifically, the stealing of a car. See Cobern v. Alabama, 273 Ala. 547, $x_{42}$ So.2d 869 (xg62). Cobern was electrocuted on September 4, I964. 
death penalty itself. The inclusion of dicta disapproving the death penalty explicitly or implicitly has not been uncommon in recent years. ${ }^{111}$ In the two most recent decisions reforming procedure in capital cases, the Court has included footnotes "doubt[ing] the ability of the death penalty ... to achieve this supposed objective [of deterrence]" 112 and quoting Arthur Koestler's charge that whether one approves capital punishment is " $[t]$ he test of one's humanity ...."113 The result has been extraordinarily stringent requirements of procedural fairness in capital prosecutions. Justice Jackson once noted that " $[w]$ hen the penalty is death, we, like state court judges, are tempted to strain the evidence and even, in close cases, the law in order to give a doubtfully condemned man another chance." 114 Occasionally, the special care shown for capital defendants has yielded explicit protections for them which do not apply to other defendants. ${ }^{115}$ More recently, the Court has addressed itself directly to the procedures peculiar to capital prosecutions, articulating principles which would invalidate many state and federal death penalty provisions ${ }^{116}$ and substantially reduce the possibility of empanelling a jury that is willing to impose the death penalty. ${ }^{117}$ Some commentators on these opinions have sought to explain them largely in terms of the Court's growing revulsion against capital

${ }^{111}$ In addition to those mentioned in text, see Trop v. Dulles, 356 U.S. 86, 99 (I958) (commenting that the arguments against capital punishment are "forceful"); Louisiana ex rel. Francis v. Resweber, 329 U.S. 459, 47 (I947) (Frankfurter, J., concurring) (deploring the state's "insistence on its pound of flesh").

112 United States v. Jackson, 390 U.S. 570, 590 n.35 (rg68).

${ }^{113}$ Witherspoon v. Illinois, 39 I U.S. 5IO, 520 n.I7 (Ig68).

${ }^{114}$ Stein v. New York, 346 U.S. I56, I96 (r953).

${ }^{115}$ See, e.g., Poweil v. Alabama, 287 U.S. 45 , $7 \mathrm{Y}$ (1932) (counsel must be provided for defendant in capital case). Justice Harlan has explicitly advocated that such a distinction be drawn under the due process clause, Reid v. Covert, 354 U.S. I, 77 (I957) (concurring opinion):

So far as capital cases are concerned, I think they stand on quite a different footing than other offenses. In such cases the law is especially sensitive to demands for that procedural fairness which inheres in a civilian trial .... I do not concede that whatever process is "due" an offender faced with a fine or a prison sentence necessarily satisfies the requirements of the Constitution in a capital case.

${ }^{110}$ United States v. Jackson, 390 U.S. 570 (I968) (declaring unconstitutional a provision of the Federal Kidnapping Act allowing only a jury to impose the death penalty, thus burdening the defendant's exercise of his right to choose a jury trial). The implications of Jackson are suggested in The Supreme Court, rg67 Term, 82 HaRv. L. Rev. 63, I60-62 (I968). But see Brady v. United States, 38 U.S.L.W. 4366 (U.S. May 4, I970) ; Parker v. North Carolina, 38 U.S.L.W. 4371 (U.S. May $4,1970)$.

${ }^{117}$ Witherspoon v. Tllinois, $39 \mathrm{r}$ U.S. 510 (rg68) (declaring unconstitutional a state law allowing the prosecution to exclude as jurors from the penalty jury in capital cases those who have conscientious scruples against imposing the death penalty). Of course, if Witherspoon is extended to guilt-determining juries as well as penalty juries, the effect on the administration of death penalty provisions would probably be much greater. 
punishment. ${ }^{118}$ The dissenting Justices have generally agreed with the commentators, arguing that "[i]f the Court can offer no better constitutional grounds than those provided in the opinion, it should restrain its dislike for the death penalty and leave the decision [to the other branches of government]," 110 and that "[i]f this Court is to hold capital punishment unconstitutional, .. . it should do so forthrightly . . . ." 120

It may be that at least some of the Justices who demand fair procedure in capital cases actually believe the death penalty to be unconstitutional. Nonetheless, the dicta expressing opposition to capital punishment have relied on essentially policy considerations. Such considerations are generally thought to be exclusively in the province of the other branches of government. The assumption seems to be that it is more appropriate for the Court to invoke the Constitution to interfere with a government's choice of procedures than to interfere with its enactment of substantive criminal law. A substance-procedure distinction is not new to the Court's self-image as constitutional interpreter. It may derive in large part from a reaction against the Court's substantive due process decisions during the first three decades of the century which substantially frustrated the movement for progressive social legislation. ${ }^{121}$

One common justification for the substance-procedure distinction is that judges have an expertise in procedural matters which they do not have on questions of social policy. ${ }^{122}$ More-

\footnotetext{
${ }^{118}$ See, e.g., A. Bicker, The Supreme Court and the Idea of Progress $70-\eta \mathrm{r}$ (1970).

${ }_{110}$ Witherspoon v. Illinois, 39I U.S. 5Io, 542 (I968) (White, J., dissenting).

${ }^{120} \mathrm{Id}$. at 532 (Black, J., dissenting).

${ }^{121}$ The current aversion to use of substantive due process limitations in the economic area is entirely proper. See Ferguson v. Skrupa, 372 U.S. 726 (Ig63). However, that aversion should not carry over to non-economic protections of individual liberties. See Griswold v. Connecticut, 38I U.S. 479, 496-99 (I965) (Goldberg, J., concurring). As the senior author of this article has written elsewhere:

There is no evidence that the framers intended the 5th and I4th Amendments to deny to the nation and the states their right of economic experimentation. There is every evidence that they intended the Bill of Rights and the I4th Amendment to safeguard the fundamental personal rights and liberties of all persons against governmental impairment or denial.

The Defense of Freedom, The Public Papers of Arthur J. Gordbego x5I (D. Moynihan ed. I966).

${ }^{122}$ Speaking of procedural due process, for example, Justice Jackson stated that "[i]nsofar as it is technical law, it must be a specialized responsibility within the competence of the judiciary on which they do not bend before political branches of Government, as they should on matters of policy which comprise substantive law." Shaughnessy v. United States $e x$ rel. Mezei, 345 U.S. 206, 224 (I953) (dissenting opinion). Justice Brandeis agreed, arguing that "[o]ne can never be sure of ends - political, social, economic. There must always be doubt and difference of opinion; one can be $5 \mathrm{I}$ percent sure." On matters of procedure, however, "fundamentals do not change; centuries of thought have established standards." A. Mason, Brandeis: A Free MAN's LIFE 569 (I946).
} 
over, the Court has sometimes recognized a limitation on constitutional regulation of the substantive criminal law, deriving not so much from lack of judicial expertise as from the complexity and subtlety of the questions involved..$^{123}$ Recognition that local conditions may differ and respect for elected representatives' latitude in enacting community moral values in the substantive criminal law surely recommend judicial caution. But too much can be made of the contrast with procedural questions.

The principal defect of the argument from expertise is the assumption that procedural questions unlike substantive ones are "technical" or governed by "established standards." None of the Court's important procedural reforms have sprung full blown from its knowledge of the judicial machinery or from clearly established rules. ${ }^{124}$ The most critical component of judicial decision usually is the set of constitutional values - the conception of fairness, of individual dignity and privacy - that informs decision. In this respect, interpretation of the cruel and unusual punishment clause is not greatly different from, for example, interpretation of the privilege against self-incrimination. "[T]he constitutional foundation underlying the privilege," the Court has said, "is the respect a government . . . must accord to the dignity and integrity of its citizens." ${ }^{125}$ Similarly, "[t]he basic concept underlying the Eighth Amendment is nothing less than the dignity of man." 126

The distinction between procedural and substantive activism may also derive from a concern to limit the power of the Court as a countermajoritarian department - to frustrate the elected departments. Reversing the judgment of a legislature on issues of procedure is thought to allow them to find other means of achieving the desired end. Reversal on a substantive question, on the other hand, may frustrate far more severely the will of the political branches. ${ }^{127}$ This argument depends upon the assumption that

${ }^{123}$ See Powell v. Texas, 392 U.S. 514, 53I, 533 (I968) (the criminal sanction functions to reflect the community's "cultural taboos" and the Court must not become "the ultimate arbiter of the standards of criminal responsibility, in diverse areas of the criminal law, throughout the country"). The Porell Court concluded that the Court should venture "but a very small way into the substantive criminal law." Id. at 533. It is likely that application of eighth amendment standards to criminal responsibility is even more difficult than application to types of punishment. See also Robinson v. California, 370 U.S. 660, 682 (Ig62) (Clark, J., dissenting); Weems v. United States, 217 U.S. $349,379-80$ (Igro); id. at $387-88$ (dissenting opinion). The same theme has been taken up by some lower courts. See, e.g., Bailey v. United States, 74 F.2d 45I, 452-53 (Ioth Cir. I934).

${ }^{124}$ Procedural protection in the "coercive atmosphere" is a familiar example. See Miranda v. Arizona, 384 U.S. 436 (I966); cf. Driver, Confessions and the Social Psychology of Coercion, 82 Harv. L. REv. 42 (Ig68).

${ }^{125}$ Miranda v. Arizona, 384 U.S. 436,460 (Ig66).

128 Trop v. Dulles, 356 U.S. 86 , I00 (1958).

${ }^{127}$ See Kadish, supra note 22 , at 359. 
procedural activism cannot foreclose most ends of public policy. It is not always easy, however, to separate the ends from the means of public policy; a procedural requirement may foreclose achievement of a substantive program, depending on the goal of the program. At some point, stringent procedural requirements may become too costly for the state to achieve certain ends and they will be effectively foreclosed. ${ }^{128}$ Social "ends" are usually not absolute, but include a component of time, money, and energy worth expending. Procedural activism may function not only to raise costs, but also to make it more difficult under any level of expenditure for the state to obtain criminal convictions, and thus to put into practice the moral judgments expressed in the statute books. In the area of capital punishment, the Court's procedural reforms have stopped many executions; they may lead indirectly to a de facto or even de jure abolition of the death penalty. When the Court raises the standards of impartiality and representativeness for capital juries, it thereby makes death sentences less likely. And, when the Court strikes down statutory death penalty provisions on procedural grounds, it forces the legislature to reconsider the provision as a whole and the legislature may respond by substituting life imprisonment as the maximum punishment.

The distinction between procedural and substantive activism may rest, finally, on the notion that our fundamental liberties are sufficiently protected if the Court confines itself to limiting the procedural excesses of the other departments. The recognition that procedural reform may substantially frustrate substantive policy, however, does not mean that procedural reform alone is sufficient to safeguard those freedoms. "Indirect" substantive reform is sometimes erratic and often ineffective. It leaves some unfortunate individuals at the mercy - and, possibly, the notso-tender mercy - of the state. The very fact that the eighth amendment proscription of cruel and unusual punishment is in the Constitution ought to condemn reliance on fair procedure alone. If an individual were afforded every procedural consideration, duly convicted of a crime and then burned at the stake, we would agree that his rights had not been "sufficiently" protected. Even a vicious criminal, fairly convicted, ought not to be thought an outcast subject to any and all abuse. That is the purpose behind the cruel and unusual punishment clause.

${ }^{128}$ On occasion, courts have required such exacting procedural perfection that one suspects that their true purpose was to undercut the substantive program involved. That end may be achieved not only by raising the cost of the program, but also by articulating procedural requirements which it is nearly impossible to satisfy at any cost. See, e.g., Coleman v. United States, 334 F.2d 558 (D.C. Cir. I964) (procedures for sentencing in a capital case). 


\section{B. Policies of Self-Limitation: Narrow and Necessary Decisionmaking}

If the Court's avoidance of the capital punishment issue is not to be explained by a qualitative difference between decision on matters of criminal procedure and substantive criminal law, it may be thought to rest on policies of self-limitation which regulate the Court's process of decisionmaking. Like the proposed distinction between substance and procedure, these policies are motivated by an appreciation of the Court's countermajoritarian position. Again, the purpose is to limit the occasions and scope of judicial interference with the actions of the other departments. Specifically, these policies counsel that Supreme Court decisions be both necessary and narrow.

The Court's decision to grant or deny certiorari is by law discretionary and the decision to hear argument on appeal has of necessity also come to depend on an element of discretion. With one exception, ${ }^{129}$ the Court has not been willing to hear argument on the constitutionality of the death penalty. Since no lower court has ever declared the death penalty unconstitutional, it may be thought that review of the question by the Supreme Court is not absolutely necessary. Despite the lack of conflict in the lower courts, however, the capital punishment issue is an unsettled one at the moment. That is due to the incongruence between the Court's doctrine of cruel and unusual punishment and its procedural chipping away at capital punishment, on one hand, and its now questionable dicta that the death penalty is constitutional, on the other hand. ${ }^{130}$ Moreover, the capital punishment issue should be decided just as the issue of racial segregation in Brown $v$. Board of Education ${ }^{131}$ should have been decided. These questions of constitutional interpretation are of such moral import and immediate significance that they must press themselves on all who are empowered to resolve them. The Court's countermajoritarian position, independent of political responsibility, should not always counsel restraint. "It is not a denial ... but rather a supreme manifestation of democracy that the fundamental rights of the least among us are protected from govern-

${ }^{128}$ See p. I798 supra.

${ }^{130}$ The Court's own guidelines for granting certiorari favor review when a lower court has "decided an important question of federal law which has not been, but should be, settled by this court." S. Cr. R. Ig(r) (b). The guidelines also favor review when "a state court has decided a federal question of substance not theretofore determined by this court" and when the lower court has decided it in a way "probably not in accord with applicable decisions of this court." Id. Ig(I) (a). All of these considerations counsel Supreme Court decision on the constitutionality of the death penalty.

${ }^{131} 347$ U.S. 483 (I954). 
ment by the Constitution and safeguarded by an independent judiciary." 132 Nor does prudential preservation of the Court's integrity recommend restraint when such issues are at stake. Since its primary institutional purpose is to protect individual freedoms, failure to do so "is far more likely to be the undoing of the Court as an institution than the faithful exercise of judicial responsibility." 133

Even when the Court decides to hear argument on the issue, however, it often applies another policy of self-limitation in its choice of the grounds for decision. As a general rule, it is said that the Court should choose the narrowest possible ground. ${ }^{184}$ Thus nonconstitutional grounds are favored over constitutional grounds. And, between two constitutional grounds it is said that the Court should select the one most nearly confined to the case before it. If the Court takes care to decide no more than it must in any one case, the degree of judicial interference with the actions of the other branches will be minimized.

The doctrine of choosing the narrowest ground of decision often has more theoretical appeal than practical application. ${ }^{185}$ It is frequently very difficult to determine which of two constitutional grounds is the more narrow. In Boykin, for example, the Court avoided decision on the constitutionality of capital punishment only to enunciate a rule for the acceptance of guilty pleas in state courts which was attacked by the dissenters as imposing unprecedented burdens on state judicial systems and improperly raising federal statutory requirements to constitutional status. ${ }^{\mathbf{1 3 0}}$ The procedural decision in Boykin, moreover, may have broad implications for waiver doctrine generally. ${ }^{137}$ No decision on a constitutional ground can really be classified as narrow unless constitutional doctrine is tied very closely to the precise facts of the case at hand. Even then, such decisions often generate broader principles which are later explicitly applied, as the progression

132 The Defenses of Freedon, The Public Papers of Arthur J. Golderrg, supra note I2I, at I49.

${ }^{133} \mathrm{Id}$. at $\mathrm{I} 5 \mathrm{O}$.

${ }^{134}$ See Ashwander v. Tennessee Valley Authority, 297 U.S. 288, 347 (1936)

(Brandeis, J., concurring).

${ }^{135}$ Even in theory, if cases are selected for argument on the basis of the importance of the federal question involved, it may be inconsistent then to decide those cases on less substantial grounds. Chief Justice Vinson once described the Court's practice as follows: "[T] he Supreme Court must continue to decide only those cases which present questions whose resolution will have immediate importance far beyond the particular facts and parties involved." Speech by Fred Vinson, ABA, Work of the Federal Courts, September 7, I949, published in 69 S. Cx. $v$, vi (r949).

${ }^{138} 395$ U.S. at $246-48$.

${ }^{137}$ See The Supreme Court, Ig68 Term, 83 HARv. L. REv. 7, I85-87 (Ig69). 
from Escobedo ${ }^{138}$ to Miranda ${ }^{139}$ demonstrates. Any constitutional decision may have implications beyond its immediate impact. The requirement of narrow grounds of decision in this context can only mean that limiting principles should be articulated. It has been shown in part $\mathrm{I}$ of this article that a holding under the cruel and unusual punishment clause can be confined to official execution.

Were the Court nonetheless to conclude for institutional reasons that the capital punishment issue should be left to the other branches of government, it might take one of two courses. First, it could hear a case raising the cruel and unusual punishment claim and declare that capital punishment is not forbidden by the eighth amendment, thereby washing its hands of the matter. Second, it could continue to decline to hear argument on the claim and go on chipping away at the procedural administration of the death penalty. The policy of necessary decisionmaking strongly recommends the latter course. A direct constitutional sanctioning of capital punishment would be not only inconsistent with precedent; it would also be a most unnecessary intervention in the political process. Its result would be a stifling of movements for reform now afoot in nonjudicial forums across the nation. The Court has great power to lend legitimacy to governmental actions hotly disputed on policy grounds. ${ }^{140}$ To give that imprimatur of legitimacy to a new, untested governmental program such as the recent civil rights acts is salutary. But to give it to a long-established and now broadly challenged type of punishment serves no purpose that abstinence could not serve as well; and it would defeat the very reason behind judicial restraint - encouragement of decision by the other branches of government.

If the Court does continue to decline to decide the cruel and unusual punishment question either way, its abstinence should not be taken as an implicit sanctioning of the death penalty. Judicial nondecision, based as it must be on institutional constraints peculiar to the courts, does not justify nondecision by other institutions not so constrained. It should be taken as an invitation to consider the issue in other forums.

${ }^{138}$ Escobedo v. Hlinois, 378 U.S. 478 (I964). A narrow holding emphasizing myriad factual considerations, like Escobedo can, of course, be criticized for creating undue uncertainty as to the breadth of constitutional protection. See, e.g., The Supreme Court, Ig65 Term, 80 HARV. L. REV. 9I, 20I (Ig66).

139 Miranda v. Arizona, 384 U.S. 436 (I966).

${ }^{140}$ See C. Black, The People and the Court 57-86 (I960). Professor Bickel also recognizes the Court's power to legitimize the actions of other departments, but shares the concern expressed in text here to limit the exercise of that power. A. Bicket, The Least Dangerous Branch 29-33 (I962). 


\section{A Declaration OF UNCONSTITUtTonality BY THE LEgISLATURE OR EXecutive}

If the capital punishment issue is to be left to the legislature and executive, it might be thought that the constitutional issue will therefore go undecided. The circuit court opinion in Maxwell v. Bishop, ${ }^{141}$ for example, concludes that "the advisability of capital punishment is a policy matter ordinarily to be resolved by the legislature or through executive clemency and not by the judiciary." Description of the death penalty question as a "policy matter" implies that the nonjudicial departments are not obliged to interpret and apply the cruel and unusual punishment clause. The theory underlying this view is that the functions of the branches of government are mutually exclusive. The legislative and executive domain is one of discretion and expediency; only the judiciary is charged with principled constitutional interpretation. Thus the death penalty may be a constitutional issue before the courts, but simply a policy question before the other branches. The upshot of this theory is that when the courts pass over a constitutional problem, it ceases to be a constitutional problem.

The purpose of this part is to argue that when the Court has declined to decide a constitutional issue, the legislative and executive branches have both the responsibility and the capacity to interpret and apply relevant portions of the Constitution in the course of their deliberations. More specifically, if the Court declines to pass on the constitutionality of the death penalty under the eighth amendment, legislatures can and should declare the death penalty unconstitutional in passing on new death penalty provisions and reviewing old ones. Similarly, executives have both the power and responsibility to declare the death penalty unconstitutional in deciding whether to veto those provisions, to enforce them once enacted, or to grant clemency if they are enforced. Indeed, when the Court avoids decision for institutional reasons, there is an even greater onus on the nonjudicial departments to interpret and apply the Constitution.

\section{A. The Appropriate Role of the Legislature and Executive as Constitutional Interpreters}

In describing the relative roles of the Court and the other departments of government, one must begin and end with a proposition fundamental to our system of government: "the Constitution, as interpreted by the Court, is the supreme law of the

${ }^{141} 398$ F.2d 138, I54 (8th Cir.) (Blackmun, J.), cert. granted, 393 U.S. 997 (I968). 
land." 142 Once the Supreme Court has decided that certain basic rights are constitutionally protected, these protections may not be diminished by any other department, federal or state. But there is nothing in our system of government which precludes the other branches from applying the protection of the Constitution when the Court has, for its own institutional reasons, declined to do so itself. Nor is there any reason why the other branches cannot apply the spirit of constitutional protections beyond what the Court has mandated. As Judge Learned Hand observed, the Constitution is "admonitory or hortatory." ${ }^{143}$ What it "does not command, it may still inspire." 144

Although the Court is supreme in the interpretation of the Constitution, supremacy demands simply that the other branches obey the Court. It does not absolve legislatures and executives of responsibility to guard constitutional rights when the Court has declined to require them to do so.

In Marbury v. Madison, ${ }^{145}$ Chief Justice Marshall wrote that "[i]t is emphatically the province and duty of the judicial department to say what the law is." But he added that "courts, as well as other departments, are bound by that instrument." 140 All citizens have a clear duty to obey what is, under article VI, the "supreme Law of the Land." In addition, federal and state officials must - again under article VI - swear an oath to "support" the Constitution.147 Indeed, one of the reasons given in Marbury for the Court's responsibility to interpret and apply the Constitution is that the Justices take an oath to support it. Chief Justice Marshall commented that it would be "immoral" to allow those who take such an oath to become the "knowing instruments, for violating what they swear to support." 148 Of course, the fact that federal and state officials take the same oath does not require that they duplicate the judicial function. But it is suggestive of an intent on the part of the framers that legislators and executives take not only policy matters but also constitutional principles into account before they act. When the Court has articulated or adumbrated constitutional principles which conflict with expedient policy, the constitutional scheme mandates that the other branches shall follow and apply these principles.

${ }^{142}$ A. Goldberg, Reflections of the Newest Justice (Address Before the American Bar Association, Section on Judicial Administration, August I2, I963):

${ }^{143}$ L. HAND, THE BIII of RIGHTS 34 (Atheneum ed. I964).

${ }^{144}$ Goldberg, Equality and Governmental Action, 39 N.Y.U.L. REv. 205, 218 (I964).

${ }_{145} 5$ U.S. (I Cranch) $137, I_{77}$ (I803). The Court quite recently reiterated the same theme. Cooper v. Aaron, 358 U.S. I, I8-I9 (I958).

${ }^{146} 5$ U.S. (I Cranch) at I80 (italics added).

147 U.S. Const. art. VI, \& 3.

${ }^{148} 5$ U.S. (I Cranch) at 180 . 
It might be supposed that a three-branch system of government, with each branch checking and balancing the others, works most efficiently when functions are separated to the greatest degree possible. However, efficiency is not simply a matter of institutional expertise; the departments must function together as well as separately. The successful functioning of the constitutional scheme depends in part on widespread willingness to respect fundamental law. Were the legislature and executive to show no constitutional restraint, the whole burden of constitutional enforcement of civil liberties would fall on the rather fragile institution of the Court. Tension between the branches might result from frequent confrontation, and the nonjudicial departments would lack the appreciation of constitutional limitations, gained through experience, which might alleviate tension. More importantly, many government actions violative of constitutional protections would go unchecked. The judiciary simply cannot right every wrong. And, even if the courts do eventually decide that government encroachment on individual freedoms is unconstitutional, a great deal of harm might have been done in the meantime. Thus it is crucial that the nonjudicial branches screen out as much unconstitutional action as possible before it reaches the courts.

To some extent, of course, the legislative and executive responsibility to interpret and apply the Constitution does require them to function in a rather Burkean role. It forbids them to reflect every whim and passion of the community at large, and commands that they take account of the "sober second thought." 140 Of course, the nonjudicial departments are not institutionally as well suited to detached constitutional interpretation as are the courts. ${ }^{150}$ Nor are they generally as able to evolve a "coherent body of principled rules." 151 But these institutional considerations simply demonstrate that it is proper that the Court be the final arbiter of constitutional protections, and that the other branches look to judicial opinions for the basic principles of constitutional law that limit their infringement of civil liberties. Although they counsel obedience to the Court, they do not necessarily command consistent inattention to constitutional interpretation.

In view of the limitations on constitutional interpretation by the nonjudicial branches, it is important to define the scope of their responsibility. The 1958 decision in Cooper $v$. Aaron ${ }^{152}$ makes clear that Article VI obliges legislatures and executives

${ }^{149}$ See Stone, The Common Law in the United States, 50 HARv. L. REv. 4, 25 (I936).

${ }^{150}$ See C. Black, The Peopie and the Court 49-5I (ig6o).

151 See A. Bicket, The Least Dangerous Branch 25 ( I 964$).^{2}$

${ }^{152} 35^{8}$ U.S. I (I $\left.95^{8}\right)$. 
to consider and obey Supreme Court holdings of constitutional law directly in point. The constitutional scheme must require at least that much. In our view, it requires more. The Constitution is a written document available to all. It is the "supreme Law of the Land," binding on all citizens. When any citizen is about to take an action that might be against the law, he consults authoritative judicial precedent for interpretation of the law; but if none is available, he does not feel free to ignore the law. Prudence, if nothing else, recommends that he interpret it in keeping with any principles adumbrated by the courts, if only to predict what the courts would do should they come to hear his case. Legislators and executives stand in the same relation to the "supreme Law" as any citizen does to any law. They must at least consult any Supreme Court doctrine that might aid in predicting what the Court will do when it eventually decides a particular question.

When the Supreme Court has consistently abstained from deciding some constitutional issue for institutional reasons, the nonjudicial branches have a special duty that goes beyond merely following a direct holding or merely predicting future judicial views. If the Court has made it clear that certain principles limit political decision on an issue, the other branches should apply them if the Court will not. The onus on them is particularly heavy when the Court has already developed the basic principles determinative of the issue, but avoids decision simply because of its own institutional constraints. Such is the case with the constitutionality of the death penalty. The framers surely intended that every constitutional protection of primary rights be enforced by someone. For legislative and executive officials to skate close to the line of constitutionality actually enforced by the Court in protecting important rights would not only seem to violate their oath to "support" the Constitution, but, more importantly, it would defeat the notion of constitutional government as a cooperative and purposive enterprise.

The Court has itself recognized this special responsibility of the other branches. In Mapp v. Ohio ${ }^{153}$ it condemned the use by state officials of unconstitutionally seized evidence since the Wolf ${ }^{154}$ decision, when the fourth amendment was held to apply to the states but not enforced against them by the Court. The fact that the Court would not enforce constitutional principle did not absolve the states. The Court stated: "[T]he state, by admitting evidence unlawfully seized, serves to encourage disobedience to the Federal Constitution which it is bound to uphold." 155 Similarly, legislators and executives ought to be aware that the

${ }^{153} 367$ U.S. 643 (Ig6x).

${ }^{154}$ Wolf v. Colorado, 338 U.S. 25 (x949).

${ }^{155}{ }_{367}$ U.S. at 657. 
principles of cruel and unusual punishment are applicable to the death penalty. They should not ignore those principles simply because the Court has not yet required obedience to them. Rather, they should independently interpret and apply the eighth amendment.

Even when the Court has spoken on an issue, obedience to its doctrine need not prevent the other departments from going beyond the Court in protecting individual freedoms. Legislatures and executives can devise new and more effective means of enforcing constitutional rights. The Court in Miranda v. Arizona, for example, explicitly noted that

Congress and the States are free to develop their own safeguards for the privilege [against self-incrimination], so long as they are fully as effective as those [required by the Court] in informing accused persons of their right of silence and in affording a continuous opportunity to exercise it. ${ }^{156}$

Of course, there must be judicial review of any new methods of enforcement to ensure that the constitutional protection has not been diluted. But, given a judicially defined right, the other branches are particularly well suited to consider more or equally effective ways of seeing that that right becomes a reality for all individuals. In Katzenbach v. Morgan, ${ }^{157}$ the Court suggested that in the process of more effectively enforcing existing rights, Congress may apply protections which the Court would not itself apply. Although the Court had previously declined to strike down voting literacy tests, ${ }^{158}$ it said in Morgan that the Congress may do so if its action is " 'plainly adapted' to furthering the aims of the Equal Protection Clause."150 Indeed, the Morgan Court went further to suggest that Congress may, under the fifth section of the fourteenth amendment, ${ }^{100}$ decide that a particular practice itself constitutes a violation of the equal protection clause even though the Court has not yet done so. ${ }^{161}$ However, it added the proviso that Congress has "no power to restrict, abrogate, or dilute [existing] guarantees." 182

${ }^{156}{ }_{3} 84$ U.S. 436,490 (1966).

${ }_{157} 384$ U.S. 64I (I966):

${ }^{158}$ Lassiter v. Northampton Election Bd., 360 U.S. 45 (1959).

${ }^{150}{ }_{384}$ U.S. at 652 .

160 U.S. CoNST. amend. I4, § 5: "The Congress shall have the power to enforce, by appropriate legislation, the provisions of this article."

161384 U.S. at 656 :

[I]t is enough that we perceive a basis upon which Congress might predicate a judgment that the application of New York's literacy requirement to deny the right to vote to a person with a sixth grade education in Puerto Rican schools in which the language of instruction was other than English constituted an invidious discrimination in violation of the Equal Protection Clause.

${ }^{162}$ Id. at $65 \mathrm{I}$ n.Io. In this footnote, the Court answered Justice Harlan's fear 
While Morgan explicitly applied only to congressional power under section five of the fourteenth amendment, its basic principle should extend to state legislatures, executives, and courts as well. No harm is done to federal judicial supremacy if the other branches go beyond the Court in protecting individual freedoms, so long as the Court continues to review these extensions to make sure that they do not undercut any existing guarantees. Indeed, such legislative, executive, and state judicial concern for civil liberties can only make the constitutional scheme work better and result in fuller enjoyment of those liberties. Thus state and federal officials should feel no reluctance in going beyond the Court in applying the judicially adumbrated principles of the eighth amendment to declare the death penalty unconstitutional.

Nonjudicial interpretation and application of the Constitution have deep roots in American history. ${ }^{163}$ One series of events in the early days of the republic demonstrates both the need for and early commitment to constitutional interpretation by every branch of government. The Sedition Act of 1798 was passed through the efforts of the dominant Federalist party in the Congress. It made it a crime for anyone to "write, print, utter or publish ... any false, scandalous and malicious writing ... against the government of the United States, or either House of the Congress . . . . or the President . . . with intent to defame the said government . . . or to bring them . . into contempt or disrepute; or to excite against them ... the hatred of the good people of the United States, or to stir up sedition within the United States ...."164 Federalist congressmen who supported the Act concentrated largely on its immediate necessity, giving short shrift to constitutional principles of civil liberty. The validity of such an Act was said to be "extremely clear." 165 And the new first amendment was interpreted narrowly in light of the English common law relating to governmental interference with speech and press. The Republican opponents of the Act, however, argued on another level. Attacking it as unconstitutional, they developed new principles of individual liberty not previously

that Congress might contract existing constitutional protections. Id. at 668 (dissenting opinion); see Cox, The Supreme Court, Ig65 Term, Foreword: Constitutional Adjudication and the Promotion of Human Rights, 80 HARv. L. REV. 9r, 106 n.86 (Ig66).

${ }^{163}$ The historical discussion of Congressional attention to the Constitution in this article depends upon D. Morgan, Congress AND THE Constitution (Ig66) [hereinafter cited as MORGAN]. Statements expressing the views of Thomas Jefferson, James Madison, Andrew Jackson, Abraham Lincoln, and Andrew Johnson in favor of some form of nonjudicial constitutional interpretation (sometimes denying judicial supremacy) are collected in P. Freund, A. Sutherdand, M. Hows \& E. Brown, Constitutional Law: Cases and Other Problems i8-22 (Ig67).

${ }^{164}$ Act of July I4, I798, ch. $74, \S 2$, I Stat. 596 (I798).

${ }^{165}$ MORGaN at 59-60. 
articulated by any court. ${ }^{166}$ Their argument focused on the constitutional principles that should govern legislative action rather than on existing judicial precedent and immediate expediency. Finally, in I8or, President Jefferson independently applied the evolving principles of civil liberty developed during the congressional debate and declared the Sedition Act to be unconstitutional. He thereupon pardoned all those convicted under the Act. ${ }^{167}$ Almost forty years later, all fines levied under the Act were repaid by Congress, again on the ground that it was unconstitutional. ${ }^{168}$

The creative interpretation of first amendment protections by Congress and President Jefferson in declaring the Sedition Act unconstitutional provides a dramatic example of nonjudicial application of the Constitution in the context of silence from the Court. However, the Sedition Act episode also gave birth to another - but improper - theory of nonjudicial constitutional application. The Virginia and Kentucky Resolutions of I798, also declaring the Act to be unconstitutional, suggested the doctrine of "interposition." ${ }^{169}$ The doctrine asserts that departments other than the Court, most often state governments, may sometimes be the final arbiters of constitutionality. In 1832 , the government of South Carolina merged this doctrine with that of "nullification," declaring that the federal tariff constituted an unconstitutional abuse of federal power that would not be obeyed in that state. ${ }^{170}$ In recent years, the assertion that the states may be the final interpreters of constitutionality has been applied directly to defy the desegregation degrees mandated by the Supreme Court. The unanimous Court in Cooper v. Aaron ${ }^{171}$ in I958 properly rejected this assumption of power in the strongest possible terms. The nonjudicial application of constitutional pro-

${ }^{188} I d$. at 60.

${ }^{167}$ President Jefferson wrote:

I discharged every person under punishment or prosecution under the Sedition law, because I considered, and now consider, that law to be a nullity, as absolute and as palpable as if Congress had ordered us to fall down and worship a golden image.

Letter to Mrs. Adams, July 22, 1804 , quoted in New York Times Co. v. Sullivan, 376 U.S. 254,276 ( 1964 ). The Sedition Act expired by its terms in $180 \mathrm{r}$ and was not re-enacted. Although the Act was never tested in court, the Supreme Court has since assumed its constitutionality. See id.; id. at 298 n.I (Goldberg, J., concurring).

${ }^{168} 6$ Stat. 802 (1840), accompanied by H.R. Rep. No. 86, 26th Cong., Ist Sess. (I840). At least since the early Igoo's the Congress has been somewhat more reluctant to undertake such creative interpretation of the Constitution. See generally MORGAN.

${ }^{169}$ See M. Peterson, The Jefrersonian Image in the American Mind 56-57 (I962).

${ }^{170}$ See id. at 58.

${ }^{171} 358$ U.S. $x$ (I958). 
tections which we are advocating here must not be confused with the interpositionist view. Legislatures and executives are free to make independent interpretations of the Constitution only when the Court has declined to decide an issue for institutional reasons or when they extend the protection of civil liberties beyond that required by the Court. Even then, of course, their constitutional applications are subject to judicial reversal. What we are arguing here is that the Court's silence on the death penalty presents an appropriate occasion for nonjudicial constitutional adjudication. ${ }^{172}$

\section{B. Legislative Declaration That Capital Punishment Is Unconstitutional}

This section and the next will examine the occasions on which the legislative and executive departments should consider the constitutionality of the death penalty. While the Court may avoid decision on a constitutional issue - for example through its power to grant or deny certiorari - the other branches cannot. Whenever they initiate, preserve, or administer such a program, they must take into account for themselves the "supreme Law of the Land."

The most obvious occasion for independent legislative consideration of the eighth amendment constitutional question here in issue arises when new death penalty provisions are to be enacted, since the duty to support the Constitution is then most sharply focused. Passage of an unconstitutional law would clearly violate that duty. Since there is serious doubt as to the constitutionality of capital punishment and since the Supreme Court has refused to decide the question, legislators are bound to face the issue.

Their duty is no less clear when legislation is proposed to abolish the death penalty. One should be responsible not only for acts but also for failure to act, particularly when inaction preserves a program one has initiated in the past. It might seem that a review of the death penalty's constitutionality would be

${ }^{172}$ An example of the appropriate exercise of nonjudicial consideration of constitutional protections is provided by the current debate over pretrial detention bills now before Congress. The Court has never explicitly decided whether the right to pretrial release (at least in those noncapital cases where there is no appreciable risk of flight) is mandated by the Constitution. Yet the hearings before the Senate Subcommittee on Constitutional Rights reflect serious concern about the possible impingement of these bills on the spirit, if not the letter, of the Constitution. See Hearings of Senate Subcomm. on Constitutional Rights, grst Cong., Ist Sess. (r969).

The senior author has argued, while an Associate Justice, that the equal protection clause actually obliges the states to act affirmatively to guarantee constitutional rights. Bell v. Maryland, 378 U.S. 226, 305 (Ig64) (concurring opinion). Such an obligation may constitute yet another type of occasion on which nonjudicial departments may apply constitutional protections. 
a waste of effort. Once a capital punishment provision has been enacted, its constitutionality has been passed upon one time by the legislature - at least in theory. This theory would make sense if it were realistic to assume that the enacting legislature gave serious attention to the constitutional issue and if the cruel and unusual punishment clause were static in meaning. However, the assumption is unrealistic and the clause is most definitely not static. Since the time when most death penalty provisions were enacted, relevant constitutional doctrine as announced by the Court has changed radically. Almost all capital punishment acts were passed long before the Trop and Robinson decisions, for instance. In addition, new facts concerning the psychological pain caused victims of capital punishment have come to light. ${ }^{173}$ And, surely, standards of fundamental decency have changed over the years.

It should be noted that Congress has an even broader power to interpret and apply the cruel and unusual punishment clause than have state legislatures. Under section five of the fourteenth amendment, it may enforce the constitutional protections secured by that amendment against violations by the states. Under Morgan ${ }^{174}$ Congress may interpret the equal protection clause of the fourteenth amendment more expansively than would the Supreme Court itself and may then enforce that interpretation on the states. The Court required only that it be able to "perceive a basis" for Congress' constitutional interpretation. ${ }^{175}$ The same reasoning should apply to a congressional interpretation of the due process clause (incorporating the cruel and unusual punishment clause) declaring the death penalty unconstitutional. Thus, at one blow, Congress might abolish capital punishment throughout the United States.

Two limitations on the Morgan principle might be suggested to stop it short of authorizing Congress to abolish the death penalty countrywide. First, it may be that the rather extraordinary congressional power to invalidate state laws extends only to the protection of disadvantaged minority groups through the equal protection clause. ${ }^{176} \mathrm{~A}$ formalistic distinction between the equal protection and due process clauses, however, cannot be seriously maintained. The language of section five clearly refers

${ }^{173}$ See note 69 supra.

174 See p. I8Io-II supra.

${ }^{175} 384$ U.S. at $653-56$.

${ }^{176}$ A somewhat similar argument was made by six Yale Law School professors with regard to congressional power to lower the voting age. N.Y. Times, April 5, 1970, § 4, at I3, col. I. A counter-argument by Professors Freund and Cox was printed the next week. N.Y. Times, April I2, I970, § 4, at I3, col. 2. See generally Burt, Miranda and Title II: A Morganatic Marriage, Ig6g SUP. Cr. REv. 8I. 
to both. The requirement that the congressional action be taken to protect disadvantaged minorities, by itself, is a somewhat more reasonable limiting principle. The theory might be that such minorities are unlikely to have much political influence in state legislatures; if their interests are ignored on the state level, federal intervention is more justified. This limiting principle, however, would not prevent congressional abolition of state death penalties. As has been shown above, ${ }^{177}$ the victims of official execution are both few in number and predominately members of social, economic, and racial minorities. A second possible limitation of Morgan is that it applies only to congressional intervention when the Congress has a special capacity to gather and evaluate the relevant facts. ${ }^{178}$ The Morgan Court emphasized that Congress has a "specially informed legislative competence" regarding literacy tests, which were there at issue. ${ }^{179}$ Although factfinding is crucial to application of some constitutional tests to the death penalty (for example, facts concerning its administration and effect on its victims), Congress probably cannot be said to have a competence in that area equivalent to its understanding of voting procedures. But it is unlikely that the Court meant its reference to the "specially informed legislative competence" to be taken so narrowly. The reasonable interpretation is that the Court was referring only to the general presumption that the factfinding capacity of the legislative branch is greater than that of the judicial branch ${ }^{180}$ in order to justify a broad reading of Congress's constitutional power under the fourteenth amendment.

\section{Executive Declaration That Capital Punishment Is Unconstitutional}

There are at least four occasions on which the executive may interpret the cruel and unusual punishment clause and apply it to stop official execution. The executive is, first, an initiator of legislation. He must also sign or veto legislation. Once a law is enacted, he must enforce it. And, finally, he may dispense executive clemency to those convicted and sentenced under the law. At each stage when the executive makes a decision regarding the death penalty, his duty to support the Constitution requires that he take account of the cruel and unusual punishment provision.

${ }^{177}$ See pp. I79I-93 supra.

${ }^{178}$ Professor Cox sees congressional factinding capacity as the primary rationale - not necessarily a limiting rationale - of the decision. Cox, The Supreme Court, 1965 Term-Foreword: Constitutional Adjudication and the Promotion of Human Rights, 80 HARv. L. REv. 9I, I07 (I966). See also Burt, supra note I76, at ro5-08.

${ }^{179} 384$ U.S. at $655-56$.

180 This seems to be Professor Cox's view. See Cox, supra note I78, at I07-08. 
Since one of the modern executive's primary functions is that of chief legislator, he shares with the legislative department the obligation to review old legislation which is arguably unconstitutional but which the Court has refused to consider. Certainly he cannot initiate the enactment of new death penalty provisions without confronting the constitutional limitation on his action. And when there is a significant public demand that a program such as capital punishment be abolished, he should respond at least by subjecting that program to the constitutional test. Applying the principles of cruel and unusual punishment, he may declare the death penalty unconstitutional and argue his constitutional opinion to the legislature.

The decision whether or not to veto death penalty legislation is particularly well suited to executive constitutional interpretation. The veto power is intended as a check on the legislature. Were the executive to play a vigorous role as constitutional interpreter, his veto might be a very rough, preliminary analog of judicial review. On several occasions presidents have vetoed legislation under constitutional provisions not yet considered at all by the Court. President Andrew Johnson, for instance, preceded the courts in interpreting the scope of federal power to protect civil rights after adoption of the thirteenth amendment. ${ }^{181}$ In recent years, presidents have shown somewhat less vigorous attention to constitutional safeguards. Of seven veto messages based on constitutional grounds in the last forty years, only one related to an issue of civil liberties ${ }^{182}$ - that in a time when constitutional protection of civil liberties has been the chief dynamic of constitutional law as applied by the Court. The rest involved legislation which the President believed to invade his authority, thus violating the "constitutional separation of powers." 183 At a time when expanded application of the death penalty is proposed and when the Court declines to consider applying existing constitutional principles to capital punishment, however, the onus on the executive is great to give close attention to the constitutional issue at the veto stage.

${ }^{181}$ Cong. GLobe, 39th Cong., Ist Sess. 1679 (1860) (Veto by President Andrew Johnson of $S .6 \mathrm{I}$ ).

${ }^{182}$ That was President Kennedy's veto of a congressional regulation of indecent material in the District of Columbia. See ro8 Conc. REc. 23545 (rg62) (Veto by President Kennedy of H.R. 4670).

${ }^{183}$ Besides the Kennedy veto, the other six presidential vetoes were: Io6 Conc. REc. 1575I-52 (1960) (Veto by President Eisenhower of S. 1508); 94 Cowo. REC. 5895-96 (I948) (Veto by President Truman of S. I004); 86 Cong. REC. 8024 (I940) (Veto by President F. Roosevelt of H.R. 3233); 69 Cong. REc. 9524-3I (I928) (Veto by President Coolidge of S. 3555); 68 Cong. Rec. 477I-78 (I927) (Veto by President Coolidge of S. 4808); 43 Conc. Rec. 2130-3I (I909) (Veto by President T. Roosevelt of S. 5473). 
The executive responsibility to apply the Constitution in enforcement and clemency decisions might seem more questionable. Both decisions are left to executive discretion, generally unreviewable by the courts. If enforcement and clemency decisions are essentially standardless, they might be thought not to offer the proper occasion for constitutional interpretation and application. Furthermore, it might erroneously be supposed that at both the enforcement and clemency stage, the executive department has a strong duty not to frustrate the intent of a law which was passed by the legislature and signed by the executive. ${ }^{184}$ The duty to support the Constitution, however, does not depend on the possibility of judicial review and it clearly overrides the executive's responsibility to apply statutory law. Moreover, the basic premise of the argument - that enforcement and clemency decisions are entirely discretionary - is incorrect. In fact, standards - often explicitly legal standards - are applied by the executive at both the enforcement and clemency stages. Enforcement patterns are often not random, but the product of conscious decision. ${ }^{185}$ Attorney General Ramsey Clark, for example, refused to enforce the provision of the Civil Rights Act ${ }^{186}$ punishing interstate travel with intent to incite a riot, arguing that the provision was unconstitutional. ${ }^{187}$ For similar reasons, he sharply curtailed investigative wiretapping. ${ }^{188}$ Thus enforcement officials who conclude that the death penalty violates the cruel and unusual punishment clause may justifiably refuse to file charges for capital crimes or may recommend life imprisonment in every capital case.

It might be expected that the executive clemency decision is less appropriately subject to standardization than the enforcement decision. A primary purpose of clemency is to provide a last chance for individualized justice, taking into account personal

${ }^{184}$ At least two governors who, in recent years, have declared opposition to the death penalty have nonetheless been unwilling to refuse to allow any executions to take place. They expressed the view that they were bound to administer the laws of their state and ought not to frustrate them altogether. They did not look to the United States Constitution to support a policy of across-the-board clemency. See Note, Executive Clemency in Capital Cases, 39 N.Y.U.L. REv. I36, r73 n.I35, I75-76 (I964).

${ }_{185}$ See, e.g., L. WeINREB, CrImotnal Process 404 (I970)' (federal prosecutorial guidelines with regard to obscenity statute).

${ }^{180}$ I8 U.S.C. § 2 Iox (Supp. IV, I969).

${ }^{187}$ Some support for Attorney General Clark's approach is found in a Supreme Court dictum in I932 where the Court commented, in the course of decision on an unrelated issue, that "[the state Attorney General] might hold ... that the statute is unconstitutional and that, having regard to his official oath, he rightly may refrain from effort to enforce it." Ex parte La Prade, 289 U.S. 444, 458 (1932).

${ }^{188}$ See generally R. HARRIS, JUSTICE 36-39 (I970). 
and equitable rather than legal considerations. In this regard, the clemency decision is much like the sentencing decision. However, the practice of executive clemency reveals that legal standards are often applied. Clemency boards often review the evidence introduced at trial and the fairness of the trial. ${ }^{189}$ On several occasions in recent years, state governors have instituted a policy of commuting all death sentences to life imprisonment. ${ }^{100}$ There are also instances of constitutional decisionmaking in an area analogous to executive clemency. Interstate rendition, like clemency, is left exclusively to the discretion of the executive. ${ }^{101}$ As in the clemency decision, individual and equitable considerations are the usual reasons for refusing rendition of a fugitive. ${ }^{102} \mathrm{How}-$ ever, there have been instances of refusal based upon violations of constitutional due process at the fugitive's trial. ${ }^{103}$ And, more importantly, there have also been instances of refusal based upon decision that the form of punishment to which the fugitive would be subjected is unconstitutionally cruel and unusual. ${ }^{194}$ Similarly, a decision to grant clemency to all convicts on death row could properly be made pursuant to a determination that capital punishment is unconstitutional. Indeed, four members of the Court have explicitly recognized the governor's role as constitutional guardian in the clemency process. "Executive clemency," they wrote, "provides a common means of avoiding unconstitutional or otherwise questionable executions." ${ }^{195}$

\section{ConcLusion}

In sum, we believe that (I) the death penalty is now unconstitutional under the principles of the eighth amendment adumbrated by the Supreme Court. (2) The Court, consistently with its institutional responsibility to respect principle and precedent, could and should declare the death penalty unconstitutional. (3) But if the Court elects not to do so, it should not legitimate capital punishment, but continue to chip away at it by enforcing strict procedural safeguards in capital cases. (4) And if the Court does follow the latter course, then the other departments - state and federal legislatures and executives as well as state courts - should

${ }^{189}$ See Note, supra note 184 , at $160-62$.

${ }^{190} \mathrm{Id}$. at $\mathrm{x} 75-76$.

${ }^{101}$ See Comment, Interstate Rendition: Executive Practices and the Effects of Discretion, 66 YALE L.J. 97 (I956).

192 Id. at I06.

${ }^{193} I d$. at I08.

194 Id.

${ }^{195}$ Louisiana ex rel. Francis v. Resweber, 329 U.S. 459, 477 (1947). 
apply the principles of the eighth amendment and declare the death penalty unconstitutional.

In practical terms, it may well be that the final responsibility will lie with state governors and legislators. More than 500 people are now confined in death row awaiting the outcome of our great national debate over capital punishment. If the Supreme Court declines either to declare the death penalty unconstitutional or to question the procedure by which it was imposed on these 500 men, then their fate rests with the governors and legislatures. If these 500 people - or any substantial proportion of them - are sent to their deaths, capital punishment will have been revived as active penal policy in the United States. The spectre of mass execution - after a moratorium of more than two years - threatens to further brutalize a nation already saturated with war, riot and crime. This generation of Americans has experienced enough killing. Official execution must be ended. And it can be ended, even if the Supreme Court does not intervene in these cases. The governors and legislatures of those states whose death rows are now occupied have the power to affect the future course of our history. Legislatures could abolish the death penalty in their respective states, an action which would obviously apply to men already on death row. Alternatively, governors could commute all current death sentences. The sparing of these $500-\mathrm{a}$ continuation of the moratorium on executions - could not help but affect our national attitude toward the death penalty. No governor should be deterred from commuting a death sentence by the notion that the Constitution, the Court, or any other principles of fundamental law somehow command that defendants sentenced to death be executed. Fidelity to constitutional principle certainly permits - indeed, in our view, it requires - commutation of all death sentences. 